University of Louisville

ThinkIR: The University of Louisville's Institutional Repository

Electronic Theses and Dissertations

1936

\title{
A history of the Louisville City Hospital.
}

Louise Hess Meyers

University of Louisville

Follow this and additional works at: https://ir.library.louisville.edu/etd

Part of the Social History Commons, and the United States History Commons

\section{Recommended Citation}

Meyers, Louise Hess, "A history of the Louisville City Hospital." (1936). Electronic Theses and Dissertations. Paper 1829.

https://doi.org/10.18297/etd/1829

This Master's Thesis is brought to you for free and open access by ThinkIR: The University of Louisville's Institutional Repository. It has been accepted for inclusion in Electronic Theses and Dissertations by an authorized administrator of ThinkIR: The University of Louisville's Institutional Repository. This title appears here courtesy of the author, who has retained all other copyrights. For more information, please contact thinkir@louisville.edu. 


\section{UNIVERSITY OF LOUISVILIE}

A HISTORY OF THE LOUISVILLE CITY HOSPITAL

A Dissertation

Subinitted to the Faculty

of the Graduate School of the University of Louisville

In Partial Fulfillment of the

Requirements for the Degree

of Master of Arts

Departnent of Sociology and Social Work

By

Louise Hess Meyers

Year

1936 
A HISTORY OF THE LOUISVILLE CITY HOSPITAL 
TABLE OF CONTENTS 
CONTENTS

INTRODUCIION

Page

I. THE LOUISVILII CITY HOSEITAL: Its iistory and Functions As a hunicipal Institition

II. THE REIATION OF THE HOSPITAL TO THE UNIVIRSITY OF LOUISVILIE WETICAL SCHOOL 37

III. THE CONTROI OF THE HOSPITAI

51

IV. THE PHYSICAI SET-UP OF THE HOSFITAI,

67

V. THE PFRSONTEL OF REE HOSFITAL

77

VI. PROVISIONS FOR THE VEIFARH OF THE PATIENTS

CONCIUSION AND RECONIENDATIONS

105

BIBLIOGRAPHY

108

APPENDIXES 
INTRODUCTION 
The Louisvile City Hospital established in 1817 is the general municipal hospital for the care of the sick poor of Louisville. The purpose of this study is to give the history of this institution in the light of the developing social consciousness of the city.

As society becomes increasingly complex, organizations and institutions evolve in order to meet the needs which are demanded by members of the community. By evoIution one does not mean a growth in size (while this may and in many instances does occur it is not a criterion). Evolution relates to quality and not quantity. We find that in this type of action the change which takes place is always revealed in the form and stmucture of the object; that it does not involve partial factors only; the whole subject is involved in the process; that evolutionary change makes it possible to adapt to environment; and that the change reveals more completely the nature and attributes of the object itself.

With increased knowledge and invention man has become less dependent upon his environment than he formerly was in a simpler society. In spite of the advantages brought to us by many of our inventions we have produced evils which we now find we must attempt to eradicate. 
The automobile has brought many injuries which because of the need, have been studied and a means of alleviating them been practiced. The modern industrial system with inadequate wages resulting in poor living conditions generally accounts for many of our prevalent diseases. In fact most of our diseases can be attributed to some maladjustment in the social system, if we are willing to look at the problem objectively.

"The individual does not stand alone, but is being constantly acted upon by the social environment in which he is placed". I Since this is true and since it is increasingly understood that man is determined by his heredity plus his environment (and by environment is meant everything with which nan comes in contact) our society through organized means attempts to provide some basts of provision for the needy.

People have to see and understand why a thing is beneficial before ther will accept it among their values of life and before they will demand its adoption in the Ilves of others. There are other motives which explain why things are accepted or rejected, but their discussion does not come within the confines of this dissertation.

Wan in his attempt to progress has unwillingly beset himself with plagues equally as serious in their effects as the epidemic diseases. As serious, I say, 1. Jesse Steiner, Community Organization, Chap., I 
because industrial diseases, automobile accidents, bring more than irmediate disaster. Wany times the resultant problems are more denoralizing and painful in their consequences than was the initial injury or disease. Personality maladjustments occur not onl\$ in the patient but also in the family group. We are strong or weak only in relation to our environment, and it is society which contributes toward the perpetuation of disease.

Becanse of these changes in our mode of living, man has been brought face to face with a cormlex reality. Accidents occur every day increasine the functions of our hospitals and health agencies. As long as we value articles which necessitate the expenciture of energy which results in such diseases and injuries we mat provioe adequa te medi cal care.

The field of $x$-ray has somene up in order to heln diagnose injurt, orthovedic surger has becone specialized because of the need of special treatrent for cases of sprains, fractures, and other injuries of the skeletel system; physiotherapy has become a recognizer service to help in the rehabilitation of cripoled patients. Knowledge increases bringing to the front these services which we can enlist to helo us if we so desire. Fortunately we have been eager to aciopt new heans of treating disease, and have not only demanded the latest irnrovements for 
those economically independent, but also have realized their value for the indigent.

We can no longer sit back complacentIy and say "let the sick take care of themselves." We no longer believe in the theory of laisse-falre. Why not? Because we realize that such indifference is disastrous. We must concern ourselves with others in society. Everything and everybody is related, entangled, and tremendously interdependent one with the other. What affects one touches the other, if not directly then indirectly. Our whole public welfare movement recognizes this vital principle and it is from this basic concept that a constructive program is today being planned.

The leaders are looking to underlying factors and are changing these as public opinton allows. Because public welfare attempts to protect from disaster, preserve the worthwhile, and prevent rather than cure problems its desired program is a broad one aimed at adequate housing, employment, recreation, in fact minirmum standards of living in all branches of life itself.

Thus man has used the hospital and related health agencies in his fight to adapt himself to his environment. He has specialized and differentiated fielós of study (medicine being one of many) as knowledge has increased, understanding has broadened and values become acceptable. 
Units carnot come into being as isolated services. Any new element coming into being causes a change of equilibrium in all the parts. Everything must attain a new degree of balance in relation to these added members. This appears in the relation, for example, of the Hospital Admitting Office to the Social Service Department, or in the relation between clinics and wards. Clinics and wards are not isolated services, but mist work together in closest co-operation in order to effect a maximum cure for the patient.

Adequate medical care is impossible of attainment without efficient medical soclal work and vice versa; both depend upon efficient administration, and each depends for full efficiency, upon the co-operation and services of the other.

The hospital is a vital developing institution, and the resources with which it has to work, the attitudes displayed towards the sick and indigent patients applying for care, are all products of its past history in conjunction with the present social approach to the care of the sick. The policies and attitudes, the resources furnished for a working basis are in large part influenced by the community in general.

Has the Loulsville City Hospital kept pace with the demands of a growing community? Has there been an evolution of functions, policies, attitudes? What is the 
present organization and management of the hospital? What are its standards of personnel? How has the social approach to disease influenced the care of the sick? This study is an attempt to answer these questions and on an introductory basis to evaluate something of the program of the institution. It will attempt to show trends through a study and interpretation of significant findings and to present some authorltative thinking in the field of hospital organization and management. 


\section{CHAPTER I.}

THE LOUISVILLE CITY HOSPITAL: Its

History and Functions As a Municipal Institution 
The town of Louisville was established by an act of Virginia in the year 1780 with a population of thirty, and was destined, due to its advantageous position at the Falls of the OhIo, to become one of the important centers of commerce of the country. The acquisition of Louislana by the United States in 1803, thus opening up the rississippi for trade, and the introduction in 1811 of steamboat navigation, gave an impetus to the growth of Louisville. The newly established Kentucky town Immediately assumed an important role in the conmerce and navigation on the Ohio River. When the river was at low tide barges and boats of all kinds had to be unloaded at the head and reloaded at the foot of the falls. Very soon word was spread by mariners and others of the hospitality extended by the citizens of Louisville, and river travelers as well as those coming through the Cumberland Gap frequently made a stop at this port.

Very soon, because of the many mariners who fell sick due to long voyages and exposure, the need for a hospital was recognized. At first the citizens assumed the responsibility of caring for sick mariners, but it became apparent with the growth of the city, and the prominence which the town was acquiring in the field of comerce, that the great number of men becoming ill on the river could no longer be cared for merely by the good intent of the people of Louisville. The pioneer community saw the 
urgent need for an institution which would provide medical care for the sick, and on February 5, 1817, at a time when the population of the city numbered about 4,000, an act of the General Assembly of Kentucky was passed for the establishment of the Iouisville Hospital Company.

Section 1 of the act reads "Be it enacted by the General Assembly of the Commonwealth of Kentucky, that

- Robert Breckinridge, Levi Tyler, Thomas Bullitt, Thomas Prather, David Fetter, Richard Ferguson, John Croghan, Peter B. Ormsby, James H. Overstreet, William S. Vernon, Paul Skidmore and Dennis Fitzhugh be, and they are hereby appointed a body corporate and politic, with the name and style of the Louisville Hospital Company, and by that nome, style and title are hereby made able and capable in law and in equity to procure by purchase, donation, or otherwise, within the town of Louisvilie, or contiguous thereto, any quantity of land not exceeding three acres, to them and their successors forever, whereon to erect the necessary and suitable buildings for the hospital aforesaid; and they are hereby authorized to raise by subscription, donation, or otherwise, any sum not exceeding $\$ 50,000.00$ for the purpose of procuring the land and building the houses aforesaid - - - $" 1$

The site for the hospital was secured through the

1. Collection of Acts Concerning the City of Louisville, An Act to Establish a Hospital in the Town of Louisville. (Section 1.) 
generosity of Thomas Prather and Cuthbert Bullitt who donated five acres and two acres respectively, at a location which is now the corner of Preston and Chestnut Streets, where the present hospital is located. It was not, however, until November 30,1821 , that ${ }^{6} 10,000.00$ was appropriated by the state of Kentucky for the purpose of erecting the building. During the following year it was recognized by the General Assembly of Kentucky that the appropriation was not large enough for the completion of the hospital and on - December 10, 1822, $\$ 6,000.00$ in addition to the first appropriation was allocated to this undertaking.

The hospital which was finished and ready for the reception of patients in 1823 was supported from a two per cent auction duty levied on all auction sales, except on articles grown or manufactured in the state. The annual revenue from this source was about $\$ 3,000.00$ and a yearly grant-in-aid of $\$ 500.00$ was contributed by the Federal Government from the hospital fund.

The opening of the hospital, which begins the public health program, marks an important step in the progress of both city and state.

In the administering of any public hospital there are two legal methods of approach, namely:

1. That included in the pauper laws which empower and require the public authority to care for the poor. 
2. That of the Public Health Laws which are concerned with the care of the sick.

Poor or Pauper Laws are those laws set up with the express purpose of providing that public authority assume responsibility for the "poor". 2

Some hospitals are administered under the Pauper Laws, one such being the largest general hospital in the United States, Cook County Hospital in Chicago. There a poor person has a claim to medical care in accordance with statutes calling for such services.

The Louisville City Hospital, on the contrary, is a municipal institution under manicipal public health administration.

From 1817 unt11 1836 the inst1tution, organized to meet a certain specific need, (in the first instance, to care for mariners), was styled the Louisville Hospital Company and was administered by a "body corporate and politic". The management of the hospital was given over to the managers of the corporation, who could elect a president and any other officers they might deem necessary for the organization and management of the institution. The managers were also authorlzed to make, ordain, establish and put into execution such by-laws, ordinances and regulations as they should deem necessary and convenient for

2. "A poor person or pauper is one destitute, helpless and in extreme want; so completely destitute of property as to require assistance from the public". (Bouvier's Law Dictionary-Baldwin's Revision) 
the good government of said corporation. ${ }^{3}$

During this early period the city had already begun to realize the need of some place for the isolation of contagious diseases.

A Board of Health was set-up in 1822 to cope with the dreadful epidenic of yellow fever which was widespread throughout the west. Louisville, however, was hard hit because of many ponds and a lack of sanftary facilities, and at this time the town was called the "graveyard of the west".

Because of successive epidemics the city administration was awakened to action and a Board of Health, consisting of Doctors Galt, Smith, Harrison, Wilson, and Tompkins, was appointed to examine into the cause of the disease and to make a report of their findings together with methods for eradicating it. Had this board been appointed earlier, much suffering might have been prevented, but already epidemics of small pox and yellow-fever had made great inroads on the population.

In 1828 the Board of Health was given Increased power, and proceeded to appoint a health officer and to establish regulations for the maintenance of health in Louisville.

By 1830 the population of Kentucky was 687,000 and in respect to numbers, the state ranked sixth in the An Act to Establish a Hospital in the Town of. Louisville. (Section 1.) 
union. Louisville with a population of 10,341 numbered among its industries, casting of iron for mills and steamboats, tobacco, pork packing, crude lumber and flour mills. By this time Ioulsville was no longer dependent on river trade for population; Industry was bringing permanent residents to this section and by the year 1835 the population was 19,967 .

The city officials had been for some tine aware that the protection of the public health was one of the first duties of goveruent. They accepted the task of removing the causes of epidemics and as early as 1833 when cholera again broke out in the city, it did not present so serious a problem because the Bonrd of Health had been active and in the preceeding five years intensive work had been done in the city in improving sanitation, and grading, building and laying off streets.

In order to meet further the needs of an organized comrmuity, it was evident that municipal institutions must be set-up. Accordingly, by an Act of Legislature, February 29, 1836, the Management of the Louisville Harine Hospita ${ }^{4}$ was given over to the Hayor and Council of the City of Loulsville who should anmually appoint a Bos.rd of Trustees, make rules and orders for the government and managenent of said institution, "employ a keeper, health officer, 5 physicians, mates, nurses, and attendents therefore, - - -

4. Note change of name from Louisville Hospital Company.

5. Provided for by An Act in the City Charter approved February 13, 1828. 
and provide bedding, clothing, fuel, provisions, medicine and such other articles as shall be requisite therein or empower the Trustees of said hospital to do so, and they shall have the general superintendence thereof - - 6 " The Viayor and Council were given "the right to prescribe rules and regulations by which persons other than those mariners who shall have pald hospital dues ${ }^{7}$ shall be entitled to the benefit of said hospital - - 8 "

Before this date the hospital was supported by a subsidy from the Federal Government, some income arising from the hospital dues, and some accruing from a two per cent tax on all auction sales in the city; since 1836 , the hospital has been maintained as a city institution supported almost wholly by city taxation.

6. Collection of Acts Concerning the City of Louisville, An Act to Provide for the Management of the Louisvilie Marine Hospital. (Section 2.)

7. In the port regulations of 1836 we find that $20 \not d$ per month was deducted from the wages of every hand on every boat landing at the port of Louisville (with the exception of slaves and apprentices. This money was to be used for the hospital, and in the event that hands were unable to pay, the captain and owners were liable to the collector. (City Directory 1836).

8. Collection of Acts Concerning the City of Louisville, An Act to Provide for the Management of the Louisvilie Marine Hospital. (Section 5.) 
At this date also, begins the policy of providing not only for such persons as have pald hospital dues, but for the sick poor of the city generally. ${ }^{9}$

A gap in our history of the hospital between the years 1836 and 1857 is due to the fact that the official reports are missing from the records. We do know, however, that in 1851 the Dispensary in connection with the hospital was authorized by a City oráinance. 10

In these years the scope of the hospital was greatIy widened with the corelation of the medical school to the hospital in the year 1833 and the growth of the city's population, reaching 68,000 in the year 1860 .

The Annual Report of the Louisville Marine Hospital from the year 1857 shows the policy of the administration towara the acceptance of pay patients. It was stated that several of the rooms set apart for private patients needed furniture. "If several of these rooms were supplied with proper quantsty and quality of furniture, they might be kept filled with private patients the entire year, and prove a source of revenue to the city. In their present condition

9. Collection of Acts Concerning the City of Louisville, An Act to Provide for the Management of the Louisvilie liarine Hospital. (Section 6.)

10. A Collection of Acts Concerning Louisville and the Charter of Louisville, 1851, pp. 641 Article 151. 
It is impossible to afford such accomodations as private patients usualig require." 11

In March 1865 the first freedman's bureau was created, and a supplementary act to continue it was passed over President Johnson's veto on July 16, 1866. Under the act, the secretary of Var could issue provisions to destitute and suffering refugees and freedmen. In 1868, however, the freedman's bureau was withdrawn from Louisville and it then became the city's responsibility to care for the freed negro. 12

The trustees realized the necessity for enlarging the building which was insufficient for the poor sick of the city, ${ }^{13}$ and asked the Mayor to consider an appropriation for this purpose. In this year it was also recognized that in order to furnish effective and competent medical care to the sick poor a regular hospital staff consisting of surgeons and physiclans must be established.

During this same year provision was made for furnishing free of all charge whatever, medicine, and medical

11. Annual Report of Louisville Harine Hospital 1857

12. Messages and Papers of President Johnson pp. 442 Louisville Municipal Report 1868 pp. 25

13. Annual Report of Louisville liarine Hospltal 1866 
and surgical aid to persons who because of poverty could not otherwise procure this care. ${ }^{14}$

An ordinance passed in 1869 called for the estab- . Ifshment of dispensaries in the Eastern and Western sections of town where indigent persons could apply for medicine and medical care and where patients unable to pay for vaccine could be vaccinated. The physicians were also expected to make home visits in urgent cases. Here we have the beginnings of our city doctors and outlying health clinics. On August 1, 1869 the Western Dispensary was opened on Rowan Street between 12 th and 13 th streets.

Realizing the need for improved accommodations, the General Councils of 1868, 1869, 1870 appropriated approximately $\$ 39,100.00$ for the remodeling of the hospltal, and during 1870 the hospital was remodeled with two new ells, doubling the capacity of the original building. It was thought at this date tiat with some aditional appropriations the building could be made one of the very best of its kind anywhere, but the report of the following year showed that already the facilities were becoming inadequate to meet increasing needs.

In $1869, \$ 3,636.22$ was derived from pay patients while in 1870 only $\$ 553.35$ was collected. The reason for

14. Laws of Kentucky, An Act to Incorporate the Louisville Dispensaries, 1866, Chapter 524, pp 466 
the decrease in amount was due to the removal of the United States Marine patients. It would appear that some of these patients were cared for in the Almshouse until 1873, at which time the United States Harine Hospital was opened. The United States had paid in 1869, $\$ 3,157.47$ for the care of these men.

In $1876,2,192$ patients were admitted to the hospital and in 1877, 2,037 entered, but of these numbers, 339 in 1876 and 132 in 1877 were admitted not as patients because of illness but as "homeless". The custorn of admitting homeless persons was abolished in June 1877. The board of the hospital asked for the removal of all persons not in need of hospital care, if residents and paupers, to the almshouse; if "vagrants" $i . e$. non-residents, to be sent to their places of residence.

During the next year a careful investigation of admissions was made and the figures showed of the total admitted, 1,945, fully one-third of the number were nonresidents.

In 1880 the percentage of deaths of the total admissions was sixteen percent, but our attention is called in the annual report of the hospital to those factors which undoubtedly accounted for the high rate. The report reads:

"1. Niany cases of accident, often resulting in speedy deaths are brought here.

2. Many patients in the wards die from old age. 
3. Often patients brought here after several weeks illness die, not so much from the orlginal disease as from previous bad nursing and neglect.

4. The hospital is, and of necessity, has been for many years, the home of the homeless consumptive for whom there is no cure". 15

During this decade the need for improved accomodation was seriously felt and requests made for money for buildings. The need of limiting admissions was emphasized and in 1886 a report by the superintendent to the City Council reads: "We have been imposed upon but very little during the year. Nearly all cases treated were worthy there being very few pretenders or imposters and but few non-residents. This was due principally to the caution taken by the members of your honorable board in issuing permits of admission".16

By 1890, however, the hospital faclities were so Inadequate that during the crowded seasons, fall and winter, mattresses had to be placed upon the floors for the patients. In 1892 some improvements and repairs were made in the hospital, and a new bullding was erected on liadison Street which increased, to some extent, the hospital capacity for the next twenty-two years.

15. Louisville City Hospital Report 1880 16. Ioulsville City Hospital Report 1887 


\section{The Last Twenty-five Years - - 1911-1936}

1911 is a memorable date in the history of the hospital. On August 15th the superintendent was notified to move the equipment, employees and patients to temporary quarters at the old University Building on Center street between Malnut and Chestnut street in order that a new million dollar hospital might be erected on the old site. 17 The tuberculou/patients who had been treated for the past three years in an annex were moved on August 22 nd to Waverly Hills and the Louisville City Hospital was vacated on August $23 r d$.

The hazards at the temporary hospital were great. The patients were housed in separate bulldings with very inadequate facilities. It was recognized that if fire broke out at night the only employees on duty, the night nurses, would be powerless to deal with the situation. Three years later, February 11, 1914, the new structure was dedicated. This hospital was recognized as one of the great municipal hospitals in America. As

17. Money for this building was raised by a bond issue. The bill creating a commision for the construction was drawn by Judge Alex $P$. Humphrey and introduced by Senator H.D. Newcomb, January 7,1910. This bill becane a law and Nayor Head appointed as cormissioners hiajor John $\mathrm{H}$. Leathers, Judge Arthur Peter, Messrs. Joseph Hubbuch Sr., and S.A.Culbertson--Journal of Labor, September 5,1914.

The building cost $\$ 942,000.00$ because $\$ 58,000.00$ was deducted from the milifon dollars raised by bond issue. This sum $\left(\frac{1}{15} 5,000.00\right)$ was used to cover expenses during the erection of the hospital, and also to provide for patients at Waverly Hills Sanatorium. 
compared with the year 1912-13, in the year 1914 the number of days stay in the hospital per patient decreased from 22 to 17 and the death rate diminished from $11.12 \%$ to $9.89 \%$. These figures are significant because they show how great an influence physical set-up has in obtainIng good medical care. The pleas during the old days were always for more adequate physical facilities in order to enable the medical and surgical services rendered to attain their maximum effects, and we see during the very first year of the use of the new stmucture the great diminution of deaths and also of days of treatment per patient, bringing a saving not only in money costs but also in human lives.

When the new structure was erected it was necessary to onit one of the stories originally planned, due to the reduction of the original million dollars by $\$ 58,000$.

By 1915 this lack was felt. The surgical wards especially were "langerously overcrowded from the beginning". 18 The annual report reads "if this story had been built we would have had ample space for the needs of the hospital for twenty years to come, but it is now manifest that in order to perfect the hospital it will be necessary to build an out-patient departinent where all the dispensary work can be done and the top story utilized for the housing of incurables and tuberculosis emergencies". 19

18. Report of the Louisville City Hosp 1tal 1915.

19. Report of the Louisville City Hospital 1915. 
The report also claimed that in order to care temporarily for the overcrowding on the wards it would be necessary to expend about $\$ 3,000.00$ to fit up a Children's Fresh Air ward on the roof, so that it could be used as a regular ward winter and surmer for both white and colored children. It was planned then to remodel the two children's wards into adult wards, in order to care for all the patients with comfort for the next few years. This ward, however, was not equipped and used until the influenza epidemic of 1918-19. At that time it was furnished to accomodate sixty to eighty patients.

In 1917 the clinical work of the Waverly Hills Tuberculosis Sanatorium became affiliated with the City Hospital, and the clinic was housed in the hospital. The Waverly Hills staff co-operated with the hospital in the transfer of cases to the sanatorium.

In this year also the working relations between the medical school and the hospital were strengthened by the appointment of the Dean of the liedical school as Superintendent of the hospital. This relationship continued until December 4, 1922, and its significance is discussed in the next chapter.

It is interesting to note that the construction of the out-patient department recommended in the report of 1915 was started on Warch 11, 1936. 


\section{WARDS}

The Louisville City Hospital is a general hospital caring for all chronic and acute curable diseases except tuberculosis. It has a rated capacity of 423 beds and 44 bassinets 20 and in the fiscal vear $1934-35$ had an average daily patient population of 395 .

The hospltal has fifteen wards as follows:

Four surgical wards - male and female-white and colored.

Four medical wards with the same classification. Two obstetrical wards - white and colored.

Two children's wards - white and colored.

Two psychopathic wards - male and female

- One isolation ward (housed in a separate builaing.)

There is a resident physician in charge of the ward, with an assistant resident and three senior intemes. The junior internes rotate every twenty-eight days receivirg training on the wards, in the clinics end in the erergency roori.

Patients are adnitted to the vards after referral by the doctor from the clinic or the emergency room and after an investigation by the Hospital Aamitting office.

20. Report of the Loulsvilie City Fospital 1934-35. 


\section{CLINICS}

Clinics or dispensaries, as they used to be called, were established originally to dispense medicines. With the growth of preventive and curative medicine these places where one could go to get a salve or a lotion have become centers of activity where the patients are given needed medication or other treatment only after thorough examination and diagnosis.

The clinics serve a three-fold purpose. They are used for the prevention and cure of disease and for the rehabilitation of patients.

Diseases many times are prevented from becoming chronic by treatinent rendered in cinics. Mch preventive work is also done not by medicine but by education which is made available to the patients by doctors, rurses, and social workers and by the establishment of well-baby clinics and educational prograns for the dissemination of knowledge. In cases where hospital confinement is indicated, the patient is adritted and after discharge from the institution the patient frequently returns to the clinic where follow-up rehabilitative work is cone.

By 1922 the following clinics had been estatlished:

$$
\begin{aligned}
& \text { 1. Nedicine } \\
& \text { 2. Surcery } \\
& \text { 3. Gymecology } \\
& \text { 4. Pediatrics } \\
& \text { 5. Orthopedics } \\
& \text { 6. Neurology } \\
& \text { 7. Proctology } \\
& \text { 8. Tuberculosis } \\
& \text { 9. Eye } \\
& \text { 10. Ear, lose and Throat }
\end{aligned}
$$


11. Dental

12. Heart

13. Prenatal

14. Venereal

15. Dermatology

By 1936, the clinic organization included:

1. liedicine

2. Surgery

3. Gynecology

4. Cystoscopic

5. Pediatrics

6. Dematology

7. Proctology

8. Neurology

9. Male Genito-urinary

10. Jar, Nose and Throat

11. Eye

12. Dental

13. Fracture

14. Varicose Vein

15. Post-operative

16. Orthopedics

17. Prenatal

18. Post-parturn

19. Wasserriann

20. Salvarsan

21. Rercury

This division still retains the major services, but due to specialization has enlarged the nurber of units. Whereas hertofore many types of diseases were treated under a particular clinic, todat we differentiate the clinics more specifically in accordance with a more complete classification of ilinesses.

The clinics which are in charge of the medical staff $f^{21}$ are used extensively for the instruction of redical students.

21. Discussed in detail in Chapter $V$. 
"All actual hedical and surgical care is given by the school of medine through its faculty members without recompense from the City Hospital".22 There are seventeen full time physicians and several part time physicians paid by the University of Ioulsville who superintend the professional services in the clinics.

Clinic space has been most inadequate, but during 1935 a new clinic adnission office, with entrance on liadison Street was opened to alleviate the congestion when patients used an entrance in the ambulance driveway on Floyd street. A large waiting room is now provided and patients no longer have to stand in long lines in the basement halls while waiting to obtain their clinic charts. Further expansion is indicated and a recent appropriation from the Federal Government through the Kentucky Fmergency Relief Administration makes possible a new clinic building on hospital ground to the west of the Floyd street entrance of the present hospital. This new building which is now under construction will include faciljties for the clinics, $x-r a y$ department, record room and social service departments. There is no investigation as to the financial status of patients entering the clinics, but it is planned to have such a service available before very long.

22. R.A.Griswold, University of Iouisville School of Viedicine and Louisville City Hospital, Reprint from the Kentucky Medical Journal, October 1935. 
Medical social service is rendered in the medical, surgical, pediatric, and obstetrical clinics. Social problems not presented under these four main divisions are handled through the general social service office. 


\section{SOCIAL SERVICE DEPARTIFNT}

The social service department at the Louisvilie City Hospital, siree its establishment in December 1917 has not only crown in size, but has evolved in the scope of its activities. From a small department nainly concerned with financial investigation it has grown until today it is an integral part of the medical, surgical, obstetrical, pediatric clinics and wards and related fielos coming under these services.

In 1915 the District Nurses Association with its volunteer follow-up work with patients discharged from the hospital, set-off a spark which set things going. It showed the need for such work on a larger and more thorough scale; it brought before the hospital officiels the importance of treating disease in its social setting and in the repont for that year we find the superinterdent enthusiastic about such a department. It was hoped that soon the hospital would be able to have a social service department of its own.

By 1917 the department was a realiby. At this early time the work was chiefly concemed with financial investigation although some dealt with social investigation and referrals to the District Nurses Association, Babies Wilk Fund Associetion, Board of Tuberculosis Hospital and the Board of Education. During this year a start was made on the work with the heart patients who were 
treated on the wards and in the clinics. Mentally retarded patients were placed in the Feebleminded Institute at Frankfort, Kentucky, on recommendation of the physicien; homes were found for homeless patients and through an arrangement with the Associated Charities, orthopedic shoes and braces as well as rellef were furnished to City rospital patients.

A prenatal clinic was established in November 1919 and social work saw a beginning on the obstetrical vards. The importance of keeping ircipient cases from becoming chronic was strongly felt and as early as this we find mention made of the great need for a convalescent ward. During the fall of 1920 a post-natal clinic was started and extensive worl was done with syphilitic mothers and babies. The nurses were an integral part of the post-natal clinic; they followed the patients for a period of six weeks, and saw to it that the nothers returned at the end of that time for a final examination.

The next year a hospital library was started whereby the patients on the wards were supplied books by volunteer workers. This service has since been discontinued, but church groups now visit and distribute periodicals and newspapers.

In 1923 there were but two workers in the social service department, and because of this very inadequate 
staff the work could only be superficially covered, and the only attempt at intensive work was done with patients on the obstetrical and psychopathic wards. A problem which began to be manifest was that of the chronic incurable cases which composed such a large percentage of the population on the medical wards. A plea was made for a municipal home for the incurables, and this still remains today a primary need. Although there are several fraternal and church institutions giving such care, the accomodations in these homes are limited; the waiting lists are long, and it is next to impossible to get one of the hospital patients there for care.

In 1923 the University of Louisville equipped and maintained a rehabilitation shop at the Louisville City Hospital which department was active for the next several years. The majority of patients receiving this rehabilitative aid were disabled. World War Veterans.

In 1924 it was estimated that $25 \%$ of the entire hospital and clinic population needed some sort of social service, but could not be cared for by the limited staff. This same year the social service department was admitted to membership in the Iovisville Community chest, which organization immediately took an active part in the formation of principles and pclicies for the department and furnished funds for two additional workers. 
Wedical social service departments, in general, have had a hard time proving their value to the hospital administrators, hence it has been necessary for the larger part of medical social work to be carried on by already existing agencies in the community or by funds contributed through private sources. The department at the Louisville City Hospital has been fortunate in obtaining financial and material support from the city adninistration as well as from the Community Chest. 23 Although the tie-up between the social service department and the Commanity Chest has been satisfactory such an arrangernent is not accepted as the best form of administration. Hospital social service departments should be an integral part of the hospital set-up under the control of the hospital administrator. The Fortland Health Center which was established in october 1926 was carrled over its transitional period from an individual social agency to a department of the City Hospital, (1930) by funds contributed by the Cormunity Chest. A social worker was maintained at the cliric until lack of funds necessitated her resignation in December 1931. The Highland Park Health Center which opened in 1930 had the services of a social worker for a period of seven months until funds were depleted.

23. The City of Louisville pays the salaries of employees in the social service department. The Community Chest appropriates approximately $1,000.00$ per year to the department for special diets, etc. 
Membership in the chest has always been highly esteemed by the social service department and its board. At a meeting of the Hospital Social Service Association24 and the Board of Public Safety in 1930 there was discussed the possibility of the city taking over the entire control of the Hospital Social Service Department without the yearIv subsidy from the Community Chest, but the part played by the organization in connection with the social service department was keenly felt, and members of the association protested against severing relations with the private agency. Reasons for the protest arose out of the desire to keep the department on a professional basis and the ability to do this was feared greatly if the Commulty Chest was asked to withdraw its material as well as professional support. It was felt also that Community chest funds could be used for articles which would make medical treatment more effective, (special diet, milk, and surgical supplies). 25

24. This association gives invaluable help in an advisory capacity to the chief of the Executive staff of the hospital and to the social service department. It helps in making policies and in determining the program for the department, and is held responsible by the Cormunity Chest for all expenditures of chest funds within the hospital. Through this board additional supplies have been secured through city funds. Annual Report of the Social. Service Department September 1934-1935

25. For the past one or two years city funds have been appropriated for some surgical supplies, car checks, crutches and canes. 


\section{HOSPITAL ADRITTING OFFICE}

In 1932 a report was made by the Committee on Medical Economics of the Jefferson County Medical Society.26

Several times throughout this study it was stated that the social service at the Louisville City lospital was inadequate and gave as proof the fact that "no serious attempt is riade to determine the financial status of patients in either the dispensary or in the hospital".27

Such a statement is fallacious, because the function of a social service department is not that primarily concerned with financial investigation. The physicians felt that many patients who entered the Louisville City Hospital were able to pay for medical care, $\mathrm{x}$-rays and laboratory fees and condemned the social service department because it was spending time doing social case worlx. It is possible that some of the doctors themselves were partly responsible for the condition which they were condemning.

If patients in moderate circumstances have to pay for $x-r a y$ and laboratory reports they may be unable to pay doctors' fees, and for this reason patients in moderate circumstances may have been sent to the Louisville city Hospital.

26. Report on Redical Economics: Kentucky hedical Journal February 1935

27. Report on iledical Economics: Kentucky hedical Journal February 1935 pp 63 
The social service department reconmended that an admitting department be set up and this was done on June 1934. The department is in charge of a social worker and the assistant is a public health statistician. The purposes of this department are threefold:

1. To see that indigent persons with residence in Louisville are given needed medical care.

2. To see that those who are financially and by residence ineligible for care at the Louisville City Hospital are referred for care elsewhere.

3. To see that those who are admitted because of insufficient funds pay something for their care, if they are able.

Hany who are admitted free to the hospital are patients who because of large families and limited incomes are unable to pay; others are patients who have recently obtained employment after a protracted spell of unemployment. All relief clients are admitted free of charge. A number of patients are admitted after signing a contract to make certain payments as they are able. 28

NON-RESIDFNTS

Persons who have not lived in the city for six consecutive months are non-residents and are ineligible for adrission. Such persons are referred to their home town officials i.e. county judge and county health officer,

28. Information as to the policies of the admitting offlce in determining eligibility on this basis is not at present available. A study in detail of this subject is proposed by the admititing office. 
providing they are indigent patients. If the non-resident is financially ineligible for free medical service in his home town he is referred to any private hospital or physician whor he chooses. If he is unfamiliar with either of these a physician is secured through the Jefferson County Medical Society Exchange (two hundred Louisville physicians and surgeons are listed with this exchange), and the doctor secured recomends a hospital (aIl eight hospitals in Louisville co-operate on the part-pay plan). Non-resident emergencies are cared for but are discharged at the earliest possible monent. JEFFERSON COUNYTY PATIENTS

No resident of Jefferson County is admitted to the hospital unless permission is granted through the Jefferson County Iealth officer. If a county patient is admitted, the City Hospital renders a bill to the County Health officer and he is responsible for the payrient. COMPENSATION CASES

These cases are not admitted unless they are emergent. If such a case is adnitted arrangements are made to transfer patient to the company physicians, to a private hospital or both, at the earliest time.

INSURANCE CASES

All accident cases are charged at the rate of \$3.00 per day plus costs of $x$-rays and extra supplies. If 
an emergent accident case is admitted and the department later finds that the patient or the one who caused the accident carries insurance a bll1 is rendered to the patient and to a collection agency (comected with the hospital admitting office), at the above rate, and the patient is sent to a private hospital at the oarlist possible time.

A. natient who has no insurence claim and who is financially unable to pay at the above rate, signs a contract, the amount of which is determined by the individual's ability to pay.

Every patient who is admitted to the hospital on a pay basis signs a contract. An attempt is made to have the amount and the rate of pament set by the patient. If the bill is unpaid on the specified date the office then sends a reminder. If there is no reply the bill is then given over for collection to an agency.

During the months of Iune, July and August, 1934, 2,832 applicants were admitted to the wards. Seventy-three, or $2.48 \%$, were referred to private doctors, private hospitals, and home county officials. Five hundred and thirtyone patients, or $18.5 \%$ of the total admitted, simed contracts to pey for thein care. During this tinee montrs period, $\$ 1,122.01$ was collected in cash by the adritting office.29 During the fiscal year september 1, 1934, to August $31,1935,11,070$ applicants were admitted to the August 1934 
hospital, 759 applicants were referred to private physicians and hospitals and to their home county officials. 1,077 or about $11 \%$ of the total adritted as bed-patients signed contracts to pay for services rendered. The department received $6,787.46$ during the year for these services. Of the total, 759, referred avay from the hospital, 370 , or $48.6 \%$ were non-residents of the city of Louisvilie.

of the total, 759, referred elsewhere, 344 or 45.5\% were found to be financially ineligible for care at the Louisville City Hospltal. Of the total, 759, 45 or $5.9 \%$ were compensation cases. 30

30. Compensation cases are those cases of persons who are injured while in the performance of their duties as industrial employees, or as the result of autornobile accidents.

Louisville City Hospital Annual Report sept.1934 August 1935 
CHAPTER II.

THE RETATION OF THE HOSPITAL TO THE UNIVERSITY OF LOUISVILIE MEDICAL SCHOOI. 
The Louisville City Hospital, as weIl as being a treatment center for the sick poor of Louisville, is also a teaching institution for the young medical student. The relationship between the medical school and the hospital is not of recent origin, but dates back to the year 1833, when the Louisville Vedical Institute was established by an act of the state Legislatire in which act it was stated "That the Trustees of the Loulsville Varine Hospital may confide the medical department of sald hospital to the Institute, and the Mayor and Council of the City of Loulsville may confide the liedical Department of the poor house and hospital to said Irstitute". I

The event which brought about the actual settingup of the Institute centered about a difference of opinion between the Faculty of Transylvania University and the citizens of Lexirgton; the Louisvilie liedical Institute being the direct descendent of Transylvania University.

Because of its advantageous position on the Ohio, Louisville at this time was assuning a prominent place in the development of the state, and on warch 6, 1837, the Nayor and Council of the city passed a resolution designating the square bounded by 8 th and 9 th, and Chestnut and Magazine Streets, for college use and appropriated $\$ 30,000$. for the erection of buildings, provided the Board of Trustees raised by subscription or otherwise, a sufficient

I. Collection of Acts Concerning the City of Louisville An Act for thie Establishment of the Louisville liedical Institute. (Section 6) 
sum to purciase a library and apparatus.

This action was taken following the dismissal of the Vedical Faculty of Transylvania in 1837, and because the citizens of Louisvilie were strongly in favor of a Medical School in this city, the hayor and Council lost no time in passing resolutions for the granting of the site and for the avropriation of funds to be used for buildings and eguipuent.

In spite of the fact that during the rear 1837 the city of Louisvilie as well as the nation was passine throurn a serious econonic denession, the city administration manaced to raise $70,000.00$ (by the sale of lots at a considerable profit). of this sun $45,000.00$ was used for the building and $20,000.00$ for apparatus. This action on the part of the city officials inatostes the creat interest which Louisvilie and its citizens have manifested toward healti problems thromgout the city's history.

There were eighty medcal students and twenty medical jurisproconce students in attendance. At the openins of the Institute the following professors gave instruction: Doctors Fenry illen, Gerles Caldwell, Tokn Esten Cooke, tunsford Pitts Yandell, Joshua Parier Flint, Jedediah Cobb.

on ifarch 2, 1838, the first cownencenent was held 
in the Second Presbyterian Church, and twenty-four candidates received the degree of Doctor of liedicine.

The folloming is a statenent from the first catalogue of the institute setting forth the requirements for graduation:

"The candidate for the degree of Doctor of Vedicine mat have attained the age of 21 years, and be of good moral character; mat have been engaged in the study of medicine for not less than a terin of 2 years; and have attended 2 full courses of lectures in sone respectable nedical school, one of which, at least, must be in the Insitute; except, that 4 years reputanle practice will be received in lien of one course of lectures. The candidate must also pass a satisfactory private and pubije exanination and vrite an acceptable thesis on sone subject relating to medicine, in the English, French, or Latin Ianguage".z These requirements vere standard in most of the best nedical colleges of the United states at this beriod.

As the builaing of the wedical school was not completed untiI the end of 1838, the first session was held in a hall in the City Workhouse in the fall of 1837, following the establishment of the Louisville vedical Institnte on October sist of that year.

The cormerstore of the Lovisville vedical Institute was laid on Febmarg 22nd, 1838, with hasonic orders and

2. A History of the Louisville Medical Institute and of the Establishment of the University of Louisville and its School of medicine, 1833-1846. Emmet Field tione, H.D. Filson Club History Quarterly, July, 1933 
the building on the South Vest comer of eth and chestint Streets, was ready for occupancy by the end of the same year. The structure which was destroyed by fire in 1856 was soon replaced. In 1908, when the school moved to the North wost comer of First and chestmut streets the stmucture became the Administration Building of the Louisville Board of Education and in 1935 became a Golored High Scinoo 1.

The Lonisville Narine Hospital, as was previously stated, was affiliated with the Institute in 1837, and duxIng the second session, 1838-9, of the school, Professor Caldwell who had come to Louisville from Transylvania deIivered the first clinical lectures in its wards. At this time, 1839-40, there were twenty-four medical schools in the country and the Institute ranked next to the University of Pennsylvania and Transtlvania University in number of students.

Due to Professor Caidwell's enthusiasm, interest and effort, a clinical amphitheatre, the first west of the Alleghanies, was added to the Iouisvilie larine Fospital and opened on Novenber $5,1840$.

Dr. Deniel Drake, who was intemationally knom, cane from Cincinnati in 1839 to accept the Professorship of Clinical Teoicine and Pathological Anatony. In an address at the dedication of the clinical ampitheatre Dr. Drake said: 
"The erection and opening of this Hall may, indeed, without ostentation, be regarded as an era in the history of medical instruction in the West. It completes the circle of opportunities and prepares the way for making those opportunities as precicus and productive to the student, as those afforded in any other city of the Union. Henceforth, there will exist no difference between your young alma mater, and the oldest schools of the nation, but what is $f$ ound in the ren who administer here, conpared with those of the most ancient seminaries". 3

The fees at the Institute were higher than at any western school and were more than at any of the eastern schools. This was due to the larger faculty, eight full time professors. The total fees were 125.00 , and an additional fee of 10.00 for the dissecting ticket for those students who wished to take advantage of such a course. In $1840 \mathrm{Dr}$. Joshua B. Flint, Professor of Surgery resigned and his place was fliled by Dr. Samul D. Gross, author of the first book in English on pathological anatomy and soon to be recognized as one of the world's outstanding surgeons. For ten years Dr. Gross taught in Louisville but resigned in 1850 to accept the Professorship of Surgery in the University of the City of Now York. This position he held but one session; returning to Louisvilie he again took up his former position and did not resign until 1856 when

3. A History of the Louisville Medical Institute and of the Establishment of the University of Louisville and its School of Medicine, 1833-1846. Thmet Field Horine, WD 
he accopted the Chair of Surgery at the Jefferson hedical College, his a lma mater.

On April 23rd, 1846, the Louisville Medical Institute became the Medical School of the University of Louisville and now ranks as the oldest of its seven faculties.

In 1859 facilities were enlarged for the clinical instruction of students. The Eastem Dispensary was established, thus offering students the opportunity of seeing the examination and treatment of all types of medical and surgical diseases. There was some actual practice allowed the advanced students. The instruction was held once a week and hacks carried the patients to and from the college. In 1864 Doctors Satterwhite and Goodman, who had established the Eastern Dispensary entered into a contract with the University trustees and a dispensary, known by the name of the University Dispensary, was built upon college grounds.

When in 1908, the University of Louisville Medical School moved to 1 ts present quarters at First and Chestnut Streets, (the city being too limited a field for five medical schools) the Kentucky School of liedicine (1850), the Louisville lhedical College (1869), the fospital College of liedicine (1873), and the Hedical Department of the University of Kentucky (1898), merged and became part of the Nedical School of the University of Louisville. 
The relationship between the City Hospital and the University was meanwhile unbroken and became fur ther strengthened when in 1917 the Dean of the Medical School was also made superintendent of the hospital. This relationship lasted until December 4th, 1922.

Prior to 1920 the medical faculty of the University provided the visiting staff of the hospital during the school year. At this time the city requested the faculty to assume responsibility for the professional care of patients during the entire year.

This responsibility was assumed by the University and more than $\$ 40,000.00$ is paid annually in salaries to members of the medical, surgical and laboratory staffs at the hospital. At the present time there are 17 full time and several part time physicians and surgeons on the staff of a total of 127 .

The positions of head of the school of lnedicine and Staff. Fxecutive at the hospital have been comired. These relations between the Hospital and the School of liedicine are based on an agreement signed on December 4,1922, between the University and the city authorities.

In 1920 the Inivent ty of misville equpped a Medical Research Laboratory at the City Kospital throngh a fund donated by a nember of the faculty. Surgical Pathology Conferences were begun in 1924. 
Through thes e meetings it became possible for the students to gain practical experience. They cond follow surgical cases from admission throngh all stages to a final diagnosis made in the patholosy laboratory.

In a Hospital report of 1925, we find the following: "After ten years, the benefits of the union of the school of Wedicine and the Louisville City Hosnital In the Departnent of Pathology are established. It has given the hospital a complete modern service at practically no expense to the City in comparison to the cost of service anything like it in a private hosital. It has afforded the school excellent opportunities for service and research. It has correlated medical science and clinical medicine in an ideal way. Its influence upon the grade of hospital work in wards and dispensaries has been great". 4

The hospital, though under the Department of Public Health, has all the medical activities suporvised by the Nedical Department of the Jniversity of Lonisville. Prior to 1923, the medical services of the hospital were all on a voluntary basis, but in this year the professional services of the hospital were all turned over to the supervision of the Nedical School of the University of Louisville. Until this time there were only thirteen internes which was a very inadequate number to care for the number of ward patients. The doctors who volunteered in 
clinics many times recelved energency calls during clinic time and the system was regarded as unsatisfactory.

TRAINING OF STUDUNTS:

The medical student has his first practical experience with a patient during his sophomore year in ledical school. The student meets this patient under the supervision of the Staff Executive and makes all examinations and engages in any laboratory or research work which the case demands. In the junior year, the class is divided into a ward group and a clinic group, each group having equal practice on these services. In the clinic a senior student acts as guide to tro junior students. Students train on the following services - Weaicine, Surgery, Obstetrics, Pediatrics, Pathology and Psychiatry, (from which service the student is compelled to make home visits in order to take a thorough and comprehensive history). In 1924, when the hospital was still under the supervision of the Board of Safety, some of the agreements were revised. Three agencies for the administration of the hospital were set up by an agreement as follows:
(1) Superintendent
(2) Staff Executive - Proressor in the Medical School - appointed by Dir- ector of Healtin on recommendation of the Dean of the liedical School.
(3) Hospital Executive Committee.

The staff executive was to have charge of all the profess- 
ional services in the hosultal, the superintendent to have charge of all non-professional services and the hospital executive committee to act in the capacity of an advisory and policy forming body.

The city furnishes funds for the administration of the non-professional side of the hospital which is in charge of the superintendent appointed by the Director of Health of the City of Ioulsville. The Director of Ilealth makes all professional appointments to the staff, but nominations are first made by the Dean of the irerical school after consultation with the Hospital Staff Executive Comnittee, consisting of the Dean of the hedical. School, a salaried teacher of wedicine, a s alaried teacher of Surgery, the Professor of Pathologt, one member of the clinical staff appointed by the Director of Health after consultation with the President of the University, and one other nember of the clinical staff appointed by the Dean with the approval of the President.

EQUIPNHINT:

The Medical School is located on the iortin West corner of First and Chestnut Streets. Recentiy an addition was completed through a loan of $182,000.00$ (total cost $\$ 260,000.00)$ made by the Public Works Administration of the National Fmexcency Relief Administration. The old building was also remodeled. The finished structure now gives not only adequate library 
space, but also doubles the facilities for research and teaching. The various clinical departinent headquarters are located in the hospital.

The University uses the hospital for the practical training of the medical students. Lectures are held at the hospital and clinic and ward work is done by the junior and senior students.

The University also has affiliations with the Children's Free Hospital, Waverly Hills Tuberculosis Sanatorlum, Babies lilk Fund Clinics and The hental Hygiene Clinic.

"Since 1931 all candidates for matriculation in the Nedical School have been required to take an Aptitude Test, given under the auspices of the Association of American Nedical Colleges". 5

The following are the requirements for graduation:

"1. The candidate must be 21 years old.

2. He must have studied medicine for four years of not less than thirty-two weeks each. The last year must have been in residence in this school. He must have satisfactorily completed the required work; and must have attained grades of not less than $75 \%$ in all courses.

3. He must have satisfied the Committee on Admissions a nd Promotions that he is a man of ability and character".

4. He must have discharged in full all financial obligations to the University".6

The student pays on entrance a matriculation fee

5. University of Louisville Bulletin, School of liedicine 1935-1936.

6. University of Iouisville Bulletin, School of hedicine 1935-1936. 
of $\$ 5.00$. During the 2nd, $3 r d$, and 4 th years a registration fee of 5.00 is charged. The tultion for regular students is 320.00 per year if paid in advance, or 192.50 a semester if paid by the semester.

The derree of Doctor of liedicine is conferred by the University and "is recognized by every state Board in the United States for both ifcensure and reciprocity; also for licensure examinations by the National Exanining Board, and by the British Conjoint Board" " This recognition is proof of the excellent rating of the school and facilities furnished by its teaching adjunct, the Lonisville City Hospital. The school is rated "A" by the American Medical Association.

The Louisville City Hospital and the Fedical. School of the University of Lous sville are so interdependent that the services of each are dependent on the other. The city administration provides its indigent citizens with a hospital, a place where they may apply for medical care. The hospital, without professional men to study, diagnose and treat the patients would be a total loss. In like manner the University of Louisville maintains staff and means for musuance of the basic studies needed by the physicians and surceons, but without patients, clinics, hospital facilities for practical anglication of their knowledge, tiney would be handicapped to an extent which it is impossible to estimate.

7. University of Loulsville Bulletin, School of liedicine $1935-1936$. 
In the set-up of the Louisvilie City Fospital and the Thivorsity of Louisvilie hedical School, we car see how well-organized co-operation has contributed to the welfare of hoth institutions.

Not only have the University and the Hospital gained, but the patients also have benefitted by the modern physical plant and equipment fumished by the city, and the latest developments in nedical science and practice furnished through the University of Lcuisville.

Authorities in the fielc of hospital managerient are of the opinion that the teaching hospital is the one nost to be desired. Reasons for this opinior are indicated in a Lonisvile City Hospital Renort of 1018 in which Dr. Taroli C. Goorwin, Superintendert of the Albany Fospital sumed wo the advantages of a teaching fospital as foliows:

11. To the ratient because of the comlete equioment such a plant provides;

2. To attending nen who mst keep to the front or be suwerseded;

3. To interres, who are forbunate enough to secure apnointments;

4. To the stucent body, which is allowed the freedor of the hospital.

b. To the training school for mirses, which always has before it the examole, of well trathed men doins careful work;

- To the surrounding cormunity, which as a result, has a higher standard of nracticing doctors in its miat;

7. To the doctors in the surroundirg country, who are able to see, in consultation and otherwise, the best men in their respective specisities; 
8. To science, because in the teaching hospltal, new therapeutic and diemostic nethods can be studied, by means of its trained cliniclans and laboratory workers, which carnot be done in the non-teaching hospital since the latter has neither the properiy gualified staff nor the equiprient". 8

8. Report of the Louisvilie City Jospital ISI8 
CHAPTER III.

THE CONTROI OF THE HOSPITAL 
From 1817 to 1836 the Louisvijle Hospitu? Company was administered by a "body comorate and politic". This body was composed of the managers of the corporation and had power to elect a president ano any other officers it might deem necessary for the organization and management of the institution, which was to develop into the Louisville City Fospital. The managers also were authorized to make, ordain, estahlish and put into execution such by-laws, ordinances and regulations as they deemed necessary and convenient for the good government of said corporation. Funds for the adrinistering of the hospital at this time came from subsidies appropriated by the Federal Govemment and the State of Kentucky, from hospital dues paid by mariners and from a $2 \%$ auction sales tax.

A change in the status and control of the institution, however, was made in 1836, when the Louisville Hospital Company becane a municipal institition known as the Louisville Warine Hospital and was administered under municipal public health laws and regulations.

With this new set-up the hospital came under the jurisaiction of the wayor and counc1l of the City of Louisville who were empowered to appoint anmully a board of trustees for the government and management of the institution. As a municipal institution the administration of the hospital since 1836 has been influenced by the set-up 
of the city administration and when a Board of Charities was instituted in Louisville in 1870 the hospital came under its jurisdiction.

Meantime, however, the health services of the city were developing and in 1893 an ordinance gave the Director of Health exclusive control of all matters relating to the supervision of the City Hospital.

The hospital is a general one administered primarily for the care of the sick poor of Louisville and to this end all efforts are directed. Secondarily, the hospital serves as a laboratory for the medical student, and the sick patient serves as material for his study and research.

As has been pointed out in the preceding chapter, such an arrangement is advantageous to both the University and the hospltal. The medical profession cannot carry its experimentation and research to a point where it will interfere with the welfare of the patient; one department should not develop at a pace which means impeded growth in another branch; these are principles which are recognized in the Louisville City Hospital.

In 1917 the Dean of the Medical School was made superintendent of the hospital, a relationship which lasted until 1922. Such a combination of duties as is Implied here is not recognized as the best method of administration, because of the fact that it places too much work on the 
shoulders of one person and may result in a conflict of interests, especially when political influence plays a part in hospital administration.

on Decomber 4, 1922, an agreement was entered into by the University of Loussille and the city officials. The results of this agreement gave the Director of HeaIth power to appoint a superintendent who would have control of the business administration of the hospltal, the budget for these non-professional services to be furnished by city funds. At the same time 1t was agreed that "the professional appointments to the staff should be made by the Director of Health, but only on nomination of the Dean of the Medical School (also staff executive) after approval by the Hospital staff Executive Committee consisting of the Dean of the Nedical School, a salaried teacher of medicine, a salaried teacher of surgery, the professor of Pathology, one member of the clinical staff appointed by the Director of Health, after consultation with the President of the University and one other member of the clinical staff appointed by the Dean with the approval of the President". I Under this set-up the responsibility for the administration of the hospital belongs chiefly to the Director of Health who is appointed by the Nayor. The Director of Health in turn appoints a superintendent to administer the non-professional side of the hospital's activities.

1. University of Louisville Bulletin, School of Medicine $1935-36$ 
In hospitals not closely allied with a medical department of a university, where the medical staff is composed of paid physicians from the community, the professIonal as well as the non-professional activities can be under the superintendent. However, where a university is affiliated, as our University of Louisville is with the Louisville City Hospital, it becomes necessary to have the Staff Executive (Dean of the Medical School) superintend the services derlved from the University. Theoretically it is generally accepted that a hospital should be divided into departments, whose heads are all directly responsible to the superintendent. This arrangement would necessarily imply that the superintendent be trained in hospital management.

In $1924 \mathrm{Dr}$. Haven Emers on and Miss Anna C.Phillips were brought to Louisville by the Communtty Chest to make a survey of the Hospitals and Health Agencies of Louisville and as a result a progressive public health program for Louisville was planned and recommendations made concerning general policies for the city and county adrinistration of health agencies.

In his report following the 1924 survey, Dr. Emerson, as a public health specialist, suggested that a city-county health unit be formed in charge of a full time professionally trained health officer appointed 
on the basis of his qualifications and made secure in his position by civil service standards and principles.

The report further recommended the appointinent by the Mayor of a Board of Trustees of the Louisville City Hospital, the appointees to be familiar with and qualified to direct hospital activities. The board should serve without pay and would serve the same functions as those commonly met by the boards of trustees of privately controlled hospitals.

Such a board would have the power to select the superintendents of the hospitals under its jurisdiction, who would be responsible for the non-medical personnel. The recommendation was that they should be accountable to the Board of Safety for the preparation of annual budgets.2 Such a set-up as that recommended in 1924 is one which as yet has not been accepted in the minds of our citizens; non-political control of welfare and health agencies is a modern principle and presupposes the realization that trained persons are the only ones who should control the administration of these programs. 3 Combining of city-county health activities under an adequately trained health officer would do much to

2. Since 1930, with the new city government set-up, the superintendent has been accountable to the City Health Departrnent, through the Director of Health.

3. For further discussion see Chapter V. 
strengthen administrative policies at the Louisville City Hospital. Under such a director the hospital would no longer be under political control, the Director of Health would be chosen on the basis of his qualjfications through civil service, and the superintendent would be selected by a non-partisan board; the professional control of the institution would remain under the University of Louisville which is of course a non-political institution.

In this reorganization as recommended by Dr.imerson, indigent Jefferson County patients who live outside of Louisville would be cared for under a central hospital set-up. 4 At present, Jefferson County patients are admitted to the Louisville City Hospital only after being recommended for admission by the County Health officer and the County Heal th Department is responsible for payment of the bill.5 Since Febmary 1936, only emergent county patients have been approved for admission by the County Health officer and other patients have been cared for in space provided in the basement of the Jefferson County Poor Farm in Jeffersontown, Kentucky.

4. The 1930 census lists the population of Jefferson County at 355,350 , and the population of the city of Louisville at 307,745. Thus the population of Jeffers on County exclusive of Louisville was 47,605 in 1930

5. This administrative policy dates from 1914 
The question may well be asked whether or not the need of indigent patients coming from Jefferson County, outside the city limits, presents a large enough problem to warrant the change from a City Hospltal to an institution maintained for all Jefferson County patients out of cornbined city and county tax funds. 6

In 1935 Louisville was awarded a Survey and Appraisal of the Health Activities and Needs of Louisvilie, Kentucky, in connection with the 1935 City Health Conservation Contest. The study was made by Dr. Carl E. Buck, Field Director of the American Public Health Associatior. The survey was awarded to Louisville as a prize in connection with the 1934 Inter-Chamber Health Conservation Contest for cities. This contest, which is nationwide is held annually under the joint sponsorship of the Chamber of Comnerce of the United States and the American Public Health Association. Each year a free health survey

6. During the year 1934-35, 368 county patients were admitted to the wards, and 499 patients received clinic care. (Totaling 867 county patients). The number of hospital days for county patients totaled 3,509, and the clinic visits numbered 773 .

- The trend is for a combination of city and county hospitals. "In both county and municipal hospitals the number of beds has increased duxing recent years. In 1923 there were 64,599 beds in city hospitals, 46,571 beds in county hospitals, and 4,701 beds in hospitals maintained jointly by city and county. By 1931 the beds in city hospitals had decreased to 61,351 but the beds in county hospitals had increased to 77,373 ; the greatest percentage of increase was in beds mairitained by both city and county governments, the figure for 1931 being 14,348". Recent Social Trends pp. 1087 
is awarded a city which has participated in the contest. The award to Louisville was made "not because of its health record or achievements, but rather on the basis of Its need for, and its likelihood of making effective use of, such a free health survey".?

The introduction to the report reads "The Grading Committee chose Louisville because in its opinion Louisvilile not only needed a survey but also nresented the most convincing evidence that it would make effective use of such a study. Letters from your Mayor, your Health officer, your Board of Trade, from the University of Louisvilie, the Board of Education, and from all the member organizations of the Health Council, together with numerous others, all pledged their co-operation in seeing to it that recommendations, made as a result of this study were put into effect". 8

First and most important among Dr. Buck's recommendations is that one which states that Louisville's "public health and specifically the Louisville City Jealth Department must be taken out of politics and kept out of politics". 9 He goes on to state unless all officers, agencies and citisens of Louisville are willing to co-operate to take the department out of politics and to help it develop on a

7. Survey and Appraisal of Fiealth Activities and Necds of Louisvilie, Kentucky, 1935, Dr.Carl E.Buck

8. Survey and Appraisal of Health Activities and leeds of Louisville, Kentucky, 1935, Dr.Carl F.Buck

9. Survey and Appraisal of Health Activities and Needs of Louisvilie, Kentucky, 1935, Dr.Carl E.Buck 
sound professional basis, the American Public Health Association will have wasted its time and the city of Louisvilte will have received no benefit from the survey. If this change is to be nade the importance of co-operation and unified narticination on the part of every member of the community cannot be over-embhasized. A broad and comprehensive program which a chance such as this would necessitate cannot be net by the skill and efforts of a few leaders in the field. Everyone must be called into play, for only when the majority of citizens understand such a program and are wling to co-operate in its support, can we hope to have it accepted and made part of our city's policies.

Dr. Buch further recomiended the appointment of a city-comty Board of Health and Hospltals to be appointed by the nayon and the County Judge. The Board would be appointed on a non-partisan basis, and would consist of eight menbers, three of whom would be physicians. Fach nember would serve for eight rears, the apposutnent of the original board being made in such a manner that one nember's tem would expire each year. The members vould serve without compensation. This body would be policy foming, with judiciary but not executive functions. The Eoard would have the power to draw up mles and regulations for 
the administration of the Fospital and the mules and regulations mare by such a body wonld have the effect of law, proviced they were not in conflict with existing state Jegislation or the mies and regulations of the state Department of Health.

This Board would also have the authority to appoint the Director of Health and the sunerintendent of the hosnital or losultals (should the provosed chronic-convalescent hosnital become a reality). These of ficials would serve at the pleasure of the Board, and each would be chosen on the basis of his experience and training in the respective fields.

In the above pronoser set-up the Director of Health would he executive officer of the Department of Fealth and the Surevintendert of the Hospitel would he eyecutive officer of the hosnital. Both these officials could rake recommendations to the soard conceming aprointments of nersonnel in their respective derartments, but the reconmendations would be approved on disaporoved by the Board.

In the opinion of Dr. Buck the success of such a plan as that stated above would deverd mon:

1. The Board beins so stronely comosed and doing such a good piece of work that the party in power would not see fit to change it.

2. The extent to which the Department of Ifealth develops and makes a record for itself under this trpe of administration.

3. And the extent to which the Board of Trade, the nember agencies of the Fealth Council and the press provide active backing for the plan and succeed in developing substan- 
tial public opinion favorable to this type of administration. 10

Dr. Buck's report in 1935 , though made some eleven years after Dr. Bmerson's, simply re-evaluates the problems and makes recormendations almost identical to those nade in 1924. The policies in the main, are the sare in both surveys though the boards recommended differ slightly in their set-un and furctions. These points of difference are not important, the principal issues beirg the change in set-up, from separate city and county officers and boards to a combined unit, and removal of health activities, includine administration of the hospital, from political control. The recomilendations relatine to the organization and control of health agencies made in 1924 have not been carried through. Just when the policies reconmended in 1824 and again re-emphasized in 1935 will be incorvorated in our commity thinking and organization is an uncertainty, but one may hone that the day for the change is not far aistant. The recent depression has possibly been responsible for developing generally the social consciousress in respect to public welfare and public health. This is evident in the relation of the Federal Govermment to state and local authority, in legislation passed in the fielos of public welfare and public health, and in the attibude

10. Survey and Appraisal of Health Activities and Needs of Louisvilie, Kentucky, 1935, Dr.Carl E.Buck 
in general of our citizens who perhaps more than ever before are eager to know what is happening in public affairs.

Our educational program no doubt accounts in part for this interest in human relations. Radios and newspapers, periodicals and literature are also agencies for making us conscious of conditions of poverty, ill health, and social conditions in general. Nian is coning to realize the great interplay of social factors one upon the other, he is gradually learning that the less fortunate group in our midst, as regards health, economic stability, and social adjustment has a claim on society for better living conditions.

Charity is in part a confession that our social sistem has failed. Today the vast mejority of the millions of men and women out of work are not willingly idle; their economic insecurity is due, in the main, to factors residing in the envirorment. It is a well established fact that the "individual does not stana alone but is being constantly acted upon by the social environment in which he is placed". It follows that society is responsible to the indiviaual for some basis of security and means of obtaining at least minimum standards in all branches of living. With the above social philosophy becoming a part 
of our education and our lives we cannot but feel that progressive neasures recormended by authorities in the field of public realth will be recognized as essential components of a program to deal with the complex problems in our modern society. With such recognition we should be assured that our hospitals will become entirely divorced from control which hampers the continuity and efficiency of their services. Such institutions will be administered as part of a larger social program by men and women especially trained and appointed on the basis of their ability.

The City Hospital is set up by ordinance as the hospital division of the Department of Public Heal.th and the following divisions are recognized in the hospital unit:

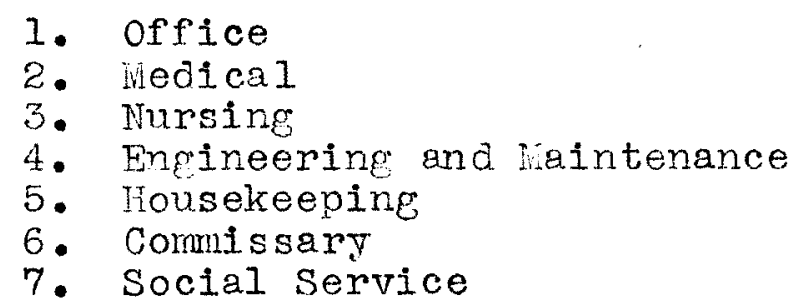

A staff is authorized by orainance for each of these departments but in actual practice the staff assigned is different from that authorized. The Griffenhagen Report on the Municipal Government of the City of Lovis- 
ville $1934-1935^{11}$ points out that this "is not intended as a criticism of the hospital authorities for failing to follow the organization indicated by the ordinance but rather to show that there is, in actual oractice, no formal organization which would provide for satisfactory Iines of authorit $y^{\prime \prime} .12$

The general control is at presert very weak. The lines of authority are not clear and too many employees report directly to the superintendent or the staff executive without intermediate supervision.

The Griffenhagen Report recommends the reorganization of the departrents into nine major subdivisions, each service to have a head who will be responsible to the superintendent. The services recommended are as follows:

"1. Administrative service, under a head clerk responsible for all record-keeping both clinical and fiscal, the purchase and storage of supplies, the ambulance, and collecting from pay patients.

11. "During the campaign of 1933, the present Adrinistration pledged that if elected, it would cause to be conducted a complete audit and survey of the city government. In fulfillment of that promise, the Board of Aldermen on March 27, 1934, passed an ord1nance authorizing and directing the liayor to cause a comprehensive audit and survey to be conducted and made an appropriation to defray the expenses thereof. Mr. Villard Cox was selected to outline the program and direct work of the audit and survey, which was begun on April 1, 1934". Foreword-i. A Report on the lunicipal Government of the City of Louisvilie $1934-35$

12. A Report on the Wunicipal Govermient of the City of Louisville, 1934-35. pp. 49 
2. Food service, headed by a dietician responsible for the operation of the general kitchen, cafeteria, and diet kitchens.

3. Housekeepirg service, under a head housekeeper responsible for all cleaning service throughout the institution including the emplorees' and nurses' homes, and for all sewing in the making of clothing for employees or patients and in the making of towels, sheets, bandages, and like items.

4. Laundry service, under a head laundry supervisor.

5. Operating and maintenance service, headed by a chief power plant operating engineer who would have charge of the operation and maintenance of the plant, of the lawn, and of watchman service.

6. Welfare service, headed by a social service supervisor responsible for making all investigations into financial conditions, home living conditions, and all other case work; and for adnissions to the hospital in so far as the social service and financial angles are concerned.

7. Nursing service, headed bi a superintendent of nurses responsible for all nursing service in the hospital.

8. Wiedical service uncier the Staff Executive which should include sections as follows:

(a) Surgery

(b) Nedicine

(c) Obstetrics

(d) Pediatrics

(e) Dentistry

(f) Psychiatry

(E) X-ray and RadiologY

(h) Laboratory

(i) Clinic 
9. out-patient service, under a supervisor of clinics responsibie for the adrinistration phases of the operation of clinics and health centers". 13

The only service which would rot be directly accountable to the superintendent would be the medical.

These recommendations of the Griffenhagen Report are not presented as final but are quoted as the recommendations of efficiency rather than professionel experts. Under the proposed set un there would be supervision of emplovees by service heads and centralized control through the superintendent which would make for efficiency of service.

13. A Report on the inunicipal Govemment of the city of Loulsvilie, 1934-35. pp. 49-50 
CHAPTER IV.

THE PHYSICAL SET-UP OF THE HOSPITAL 
Until the first quarter of the twentieth century it has been stated by Dr. Michael k. Davis that our hospltals and clinics were simply institutions for the relief of the sick poor; since that time they have become institutions for the practice of medicine. I

The reasons why hospitals were nothing more or less than places where one could be confined to bed with some little medical treatnent, was because knowledge was so linited. It was only eight years before the establishment of the Louisville Hospital Company that Dr. Ephraim incDowell had undertaken to do an abdominal operation for removal of a tunor. "It was an unheard-of risk to take. No such operation had ever been carried out. The dressing of wounds, the care of broken bones and sprains, amputation, stones, ruptures, tracheotomies, these were at that time the whole scope of surgery. A serious abdominal surgery did not exist".2

With the advent of antiseptics and anaesthetics during the middle of the nineteenth century the whole field of medicine and surgery was revolutionized. Along with these changes in techniques and methods of treatment necessarily came the need for a different physical set-up which would include facilities to care for these new services. Such has been the problem throughout the history

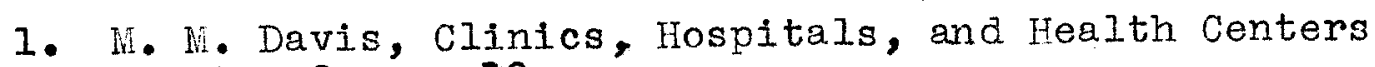
Chapter 2, pp. 10

2. Sigerist, Henry, American Nedicine pp. 88 
of the hospital; there has been a continuous plea on the part of the administration for physical facilities equal to the medical and surgical services rendered. It has been noted by the writer in reading over the annual reports that not in any instance has the professional service been referred to in a condemnatory manner; the staff has always been of highest standing in its profession, but in some instances it has been hampered by too limited a number of men. Wearnesses in administrative policies and phvsicel set-up have sometimes been cited, however, and probably with justice. The original hospital which opened in the year 1823, was described in the City Directory of 1832 as a spacious building which consisted of a center edifice of three stories and two wings of two stories each. The capacity of the building cannot be ascertained definitely, but it was probably built to accomodate about seventy-five patients.

As has been stated elsewhere in this paper no records of the happenings of the hospital can be found between the years $1836-1857$.

When we do take up the story again, hovever, we find that the population of Louisville had gromm from 4,000 inhabitants in 1823 to about 68,000 in 1857. The hospltal had endured great wear and tear and its capacity 
had become obviously inadequate. The trustees realized the necessity for enlarging the building which they said was insufficient for the poor sick of the city.

In the rears 1853-69-7C the Gereral Councils of the City of Louisville appropriated a total of approximately $39,100.00$ for the remodeling of the hospital. The new addition, consisting of two ells, contained a kitchen, wash room, dead house, two dining rooms for convalescent patients, nine aditional wards containing 250 beds (two of these wards contained fifteen beds each and were set aside for pay patients). The reinodeling did not include a modern laundry which was urgently needed as all laundry was beine done by hand and this improvement did not take place till 1884. In 1887 an entire new systen of plumbing was added. Nevertheless, inadequacies in the phrsical setup continued to be feit; changes do not come about over night, and recommendations had to be made and remade before they were finally put into actual practice.

In 1890 it is reported that the hospital facilities were so inadequate that during the fall and winter, (crowded seasons) mattresses had to be placed upon the floors for the patients.

By 1808 knowledge had incressed to such an extent that sursery was becoming a specialized service with particular techniques. In order to care for cases needing this type of treatment operating rooms were installed. 
It is recognized that in order to raise standards of diagnosis and treatment, physicians and surgeons mut be interested in the reasons for their failures as well as their successes. To this end the hospital constructed and put into use in the year 1897 an autopsy room.

In 1899 an electric light plant and cold storage system were installed; two children's wards and two emercency rooms in connection with the operating rooms were added by partitioning off useless space.

In 1900 the clinical amphitheatre vas completely reinodeled and five rooms were partitioned and furrished for the care of cases of insanity, deliriun trenens, and contageous and infectious diseases which could not be sent to the Eriptive Fospital. Two children's wards were furnished and an intercommicating interior telephone systen was installed. A unit separate fron the main hospital builing for the treatinent of infectious and contagious diseases of childhood and one for tuberculosis patients were greatly needed.

In 1901,147 active cases of tuberculosis were treated in the public wards. Mhen viewed in the light of our present accepted standards of control, this was an appaline situation, but in 1901 policies as to segregation vere not so wel]. defined. 3

3. The Cincinnati Hospital had already established a branch for consumptives in 1898, thus elleviating the congestion on the wards and segregating tine tuberculous from the non tuberculous incapacitated patient. 
In 1904 the National Tuberculosis Association was organized and the impetus given the United States by its educational program was probably responsible fn part for the opening of a tuberculosis annex in september 1908. Tubercular patients were cared for in this unit until August 22, 1911, when they were transferred to waverly Hills Sanatoriun, a city-county institution.

By the beginning of the 2oth century some relation between diet and certain diseases, such as diabetes and typhoid, was being recognized. Special diets were being used in treatment and in 1904 a diet kitchen was opened. on January 7 , 1910 the bill creating a comission for the construction of a new hospital to be built on the original site was drawn up. This bill became a law, and money for the erection of the building was raised by a bond issue.

The new hospital costing $\$ 942,000.00$ was opened on February 11, 1014. The hospital is of yellow brick construction, and consists of a group of eleven bulldings, separated by open courts. Three of the buildings, isolation, nurses home and employees home are situated as a separate group, and the other elght are connected by a long corridor running east and west.

on the fourth floor are the offices of the staff executive, medical laboratories for blood chemistry, basal 
metabolism, and electrocardiographic work. On the third floor is a complete and modern $x-$ ray and radiology department, operating rooms and four surgical wards and internes quarters.

on the second floor are two obstetrical wards, two pediatric wards and the female psychopathic ward (carIng for both white and colored females) ano record room. On the first floor, around the main lobby are the offices of the Superintendent, Superintendent of Nurses, Social Service, and a waiting room where some staff meetings are held. There are also four medical wards, a male psychopathic ward (caring for both white and colored males), a psychiatry office and an office for the Director of the Social service on this floor. At the rear are the cafeteria, nurses' dining room, internes' dining room, and dining room for those employees and social workers who desire to buy their meals in this fashion. Also in the rear is a large amphitheatre for lectures and clinics for junior and senior year medical students.

In Hall I in the basement is housed the emergency room, hospital admitting office, venereal dispensary office, and drug store.

In Hall III are the elevators, diet kitchen, and matron's office. 
In Hall $V$ we find the morgue, autopsy room, pathological and bacteriology laboratories, and recently the City Health Department moved their laboratory to the hospital.

Halls I, II, and IV have housed the clinics, but the number of patients applying for clinic care has grown to such proportions that this space is and has been for a number of years inadequate to meet the needs. Clinics are held from early morning until late afternoon, the schedules having been arranged to make maxinum use of the limited space.

During the year 1932 the Jefferson County vedical Society appointed a comittee to report on herical Economics. The work done by this committee is similar to that carried out by the Committee on the Costs of Nedical Care. 4

An extract from the Jefferson County report reads, "It is clearly demonstrated that increased dispensary space is needed when the existing physical plant actually fails to care for the city's sick poor". 5

This is simply a reemphasis of a request for a clinic building made as early as 1915, mentioned in nearly every annual report, and recommended by Dr. Frnerson in 1924.

4. Published as liedical Care for the American People, The Final Report of The Committee on the Costs of liedical Care, University of Chicago Press

5. Kentucky Medical Joumal, Volume 33, No.2, Febmuary 1935 Report on Miedical Economics, pp. 60 
A period of twenty-one years has been necessary to create in those in authority a desire strong enough to demand for the slok poor of Louisville adequate facilities for their ambulatory needs. Due to the aspirations and efforts on the part of our present administration $4446,000.00$ has been obtained from Public Works Administration Funds for the building of the long needed clinic. Ground was broken on Warch 11, 1936 and the structure is expected to be coinoleted within six months.

The builaing which is to be erected west of the nresent hospital, on ground forinerly used as a space for a tennis court for internes and doctors, will increase the capacity of the present accomodations by eighty beds. The construction will follow that of the main building and clinics will be housed here.

This is just one instance of permanent improvements which are beine made under the Public Woriss Administration's program, and is evidence of the developing social consciousness of our day. When this building is finished, the City Hospital will have advanced another step along the way in providing for the city's sick poor. During the early part of 1935 the hospital was enabled, with the aid of Kentucky Fmergency Relief Administration labor to build an extension of three rooms in the basement. Two of these rooms are used to store 
supplies, which are now bought in wholesale lots. The other extension, with entrance on Madison street provides a large waiting room which cares for patients waiting their turn to obtain charts at the clinic window. This space alleviates congestion in the basement hall where patients formerly had to stand while wating to see the clerk at the desk.

Wuch, however, remains to be done in the way of physical improvernents.

The facilities for the treatrent of acute communicable diseases in the City of Loussille are inadequate. The only provisions for the confinement of such cases are made in the isolation ward at the City Hospital. As early as 1924, Dr. Fmerson reported: "The provision for hospital isolation for cases of acute communicable diseases at the City Hospital is not only insurficient in amount but of a character that fails to meet the minimum requirements for the prevention of cross infections and of cleanliness or comfort for the patients". 6

A later study made in 1932 by the Committee on Nedical Economics volces the following indignation regarding facilities for isolation in Louisville. "The particular tragedy of the City Hospital is Isolation. It is the 6. Emerson and Philips, Hospitals and Health Agencies of Louisville, 1924, pp. 14 
city's and county's pest house. It has housed leprosy. It contains measles, scarletina, erysipelas, whooping cough, chicken pox, and fulminating cases of syphilis, also diphtheria. One would imagine this would be a large bulling so arranged that this terrible array of diseases could be kept free from cross infection. It should be, but this Pandora's box consists of only fourteen rooms and twenty-eight beds and no disease is really isolated, so that a victim entering with one disease usually acquires other diseases in this miserable place of cross infection. It has no operating room, so that the operating rooms in the main hospital have been compromised by these cases in operative complication. The staff feels, has felt for years, that isolation is a disgrace to the city and a menace to a great many people, most of them babies".7

7. Kentncky liedical Journal, Volume 33, No.2, pp. 60 Report on Viedical Eiconomics 


\section{CHAPTER V.}

THE PERSONNEL OF THE HOSPITAL 
No other part of our hospital study deserves more attention than does that of personnel. Particularly is this true today in our era of specialization. Forrierly, when knowledge was limited, practically all services could be rendered by the family physician in the home. The first hospitals cared for the indigent only and were little more than boarding places with nursing care, but this is no longer true; now our hospitals render service to those who can pay as well as to those who cannot and include modern diagnostic and therapeutic facilities for all classes of patients. The services in the hospital have enlarged in scope as knowledge has extended. No longer is the doctor able to give isolated service; he must call upon his colleagues, upon the hospital, the dietician, the physiotherapist, the social service worker in order to make his treatment effective. These professional services presuppose certain training and although we may have had untrained workers in the past who have made a real contribution on the job, we are no longer content to have such conditions continue. It is recopnized that only through training can the specific techniques peculiar to each profession be acquired, and that work can be adequately done only through the exercise of scientific principles.

A. though private agencies have been able to take the lead in emploting trained personnel, today we find 
public agencies following in the same direction, possibly because of two reasons; our public official\% have had proved to them that professionally trained people can do the job more efficiently thus curtalling expenses, and have, through public opinion, been roused to provide for those applying to public agencies, services as adequate as those provided for under private auspices.

The Louisville City Hospital which has been administered as a municipal institution since 1836 has been affected by changire city administrations. Regardless of the efficiency attained at any one time in the non-professional services, there has never been continuity of program due to the chance of personnel with each changing city administration.

The personnel of the Louisville City Fospital is composed of those persons having duties under the non-professioral administrator, 1 the director, and those performing professional or semi-nrofessional services ${ }^{2}$ under the staff executive of the hospital.

In $1832^{3}$ the resident physician and surgeon also

1. This group consists of employees having to do with administration, upkeep and maintenance.

2. Professional and semi-professional grouns irclude medical and surgical staff, social service, nursing, dietetics and medical record staff.

3. The Louisville City Hospital was at this time still called the Louisvilie Hospital Comnany. 
acted in the capacity of superintendent. 4 From that date until the 60's the men who took over the supervision of the hosnital were nearly all trained in the medical profession. During the $60^{\prime} \mathrm{s}$ and for a period of nearly twentryears thereafter, the Louisville City Hosoltal was in charge of a woman superintendent. No firdings have been made as to her qualifications, but she held the position for approximately twenty years and the annual reports of the Gity Govemment remark about her "prudent econory". The majority of superintendents have been laymen and from 1893 until the present, a period of thirty-seven years, the hospital has had twelve superirtendents, making the average length of stay for each man thirty-seven months. After a superintendent takes control at least twelve months is spent in learning the hospital set-up, in dismissing the former and training the new personnel. Under the most favorable circumstances it is impossible to have a smoothly muning organization under these circumstances. The old staff, instead of spending full time discharging its duties must take time to train the new workers. Such a system is a poor one and this fact has been recognized by authorities in the field of hospital management.

A portion of a study made in 1922 by the Conmittee 4. His salary was derived from a charge of $40 \%$ per day on each patient received into the hospital. 
on the training of Hospital Executives reads as follows: "most of the present hospital surerintendents have either drifted into the work without special training or have come up through a systen of apprenticeship - - The latter plan has rendered an excellent contribution but represents a method of preparation for professional work now largely abandoned in ther fields. Education in general has passed through the phases of apprenticeship, didactic instruction, demonstration instruction, and is now evidently entering a phase of disciplinary training". 5

There have been several hospitals which have set up some formal training for hospital superintendents. During the fall of 1935, a six weeks course was beld at the University of Chicago for training in hospital administration.

The preceding report further states, - "ith proper elasticity in interpretation, a university decree or its equivalent should be a prerequisite for the training. Thile it may not be possible to prescribe the content of the preparation, it obviously would be desirable that it include the elements of such subjects as blology, psychology, social science, bacteriology, chemistry and physics. Those with medical training and a fund of knowledge, aptitude and ability in administration have the greatest opportunity to 5. Committee on the trainirg of Hospltal Executives, Principles of Hospital Administration and the Training of Hospital Executives, 1922 pp. 18 
contribute to the broad program. These requirements are in thenselves insufficient wjthout evidence or promise of executive capacity as such, the iragination to visualize programs and policies distinct from details, ability to manage personel and prouns and to act upon as well as to make wise decisions". 6

The would be administrator should be given theoretical as well as practical work in hosptial-comunityhealth problems.

The Comittee presentea a program designating the relative inportance of each subject for a vell-rounded preparation for hospltal administration.

1. Public Tealth $(20 \%)$

2. Social Science (15\%)

3. Organization $(15,3)$

4. Hosnital Functions and History (10\%)

- Business Science (10\%)

6. Institutional lanagement (10\%)

7. Fersonnel Administration (5/?)

8. Community Hospital reeds $(5, b)$

9. Physical Plant (5)

10. Juxispruence $(5) " 7$

Ir addition, of comse, to the theoreticel courses which would cover a beriod of at least nine norths, six months of rractical work should follow under educational supervision. It was pointed out that the course vould

6. Principles of Fosnital Administrati on aro the Training of Iosutal Fxecutives, 1922 pp 19

7. Principles of Hospital Administration and the Training of Hospital Executives, 1922 pp 21-24 
provide only a good foundation for an executive. These educational standards laid down by the Committee on the trainine of Bospital Executives indicate that the position of Hospital. Administrator is at last placed on a plane with the other proressions.

As to bypes of superintendency, this same Comittee in 1927 reported thet from a study made of 6,830 hospitals in the united states the following served as administrators:

Physicians 2,668 (39.1\%)

Registered Tirses $1,283(18.8 \%)$

Lay persons in Charce $2,820(41.1, \%)$

Unimown 69

It is possible that we nay have been justified in

In the past/using untrained hospltal aiministrators, but with increased educational facilities for Eospital Ixecutives and the inauguration of the merit sister even in politically administered institutions we should no longer be limited to this standard of service.

In 1894, after baving survered the hospitals and health agencies of Loujsizle, or. Faven Wuercon of the collere of phystoians and Surceons of Colmota tuiversity recomended that the entire personnel of the renartwent of Fealth of the city of Inusvilie he put upon civil service status and that no appointment be made arcept on qualifications, and no discharges except for cause". 8. Fmerson and Philips, Hospitals and Health Agencies of Louisvilie, 1924, pp 164 
With such a set-up the superintendent of the hospital would not change with each administration, but could look fomard to securtty accoraing to civil service standards.

In the past several nonth a bjul for the incorporation of such a systen has been dram up by the Director of Health in co-operation with the head of the Department of History and Political Science of the University of Louisvilie. Its political fate has not vet been decider. Tnder the present system the superintendent is a political appointee usualIy untrained, and we find that the Director of Health has to toke a very active part in the adninistration of the hospital. According to authorities on hospital organization a division of authority, such as a setmu as this necessitates, is not the best arrangement for efficiency.

All non-professional enployees are under the supervision of the superintendent. The anmual salaries range from 378.00 for laundresses to $\$ 2,220.00$ and full maintenance for the superintendent.

The Conmittee on training of hospital executives of the American Hospital Association has ontilined the essential status of a hospital superintencient. 9

9. "First and foremost, then, a sworintendent mst be recognized as having, complete adninistrative change of all the depertments and is the first adninistrative authority in all matters concerning the welfare of the hospital and its patients - The centralization of authority in the superintendent is not an aroitrary conclusion but involves a fundamental principle of organization. It is necessary in a hospital that the superintendent be held responsible for its adminis- (con't) 
It was suggested by the Griffenhagen Efficiency experts that in order to secure a fully trained hospital executive 10 residence requirements should be waived and salary should be increased.

9 (con't) tration and it is unreasonable that he be held accountable unless he is given sufficient autiority to control conditions uoon which the patient devends. If his authority be in any way curtailed, he then can be held responsible only to the extent of his authority". Report on the Iiunicipal Goverment of the City of Lovisvilite, $1934-35$ pp.47

10. "In order to secure proper administration of a hospital the size of the City Fospital, it will be found necessary to employ a ohysician who can meet such minimum qualifications as the following: Grabuation in fiedicine from an institution of recomized standing; 8 years of experience as a practicing physician or hospital executive, of which five years shall have been in the capacity of Superintandent of a ceneral hospital, or of first Assistant to the Superintendent of a large, high ranking institution of like kind; thorough knowledge of the principles and practices of medicine and surgery; a high degree of demonstrated ability to plan, supervise, and direct the work of a hospital and all its services; tact, sunerior judgment, and good address". - - "Appointment should be made by the Director of Health from a list of rominees submitted by the University, acting tinrough the Dean of the School of Nedicine and the President of the University". Report on the Iunicipal. Government of the City of Louisville, $1934-35$ pp. 47 


\section{PROFESSIONAL SERVICES:}

HEDTCAL:

In 1832 the medical care of patients was provided for by five attending physicians and a resident physician and surgeon who also acted in the capacity of superintendent.

By 1848 there were ten attending physicians and surgeons, six consulting physicians and surgeons, and three resident physicians. The nursing was done by three male and one female nurses.

In 1873 the visiting staff consisted of six physicians, six surgeons, four clinical professors, two oculists, and four resident graduates.

Until 1922 the University of Louisville liedical School provided a hospital visiting staff only during the school year. The care of the patients during the sumner months was provided through appointments made by the Board of Public safety. At this time, however, an agreement was made between the City Administrators and the Board of Trustees of the University of Louisvilie. Through this agreement the professional side of the hospital was placed under the direction of the school of nedicine, the faculty of the school becoming the staff of the hospital.

"The faculty at present consists of 127 members, 17 of whom are on a full-time salaried basis and do not do 
any outside work. There are several part-time teachers. Hore than $\$ 40,000.00$ is paid annually in salaries by the University to the full-time and part-time members of the Medical, Surgical, Obstetrical, Pediatric and Pathological Departments, as well as to the interne staff of the Louisville City Hospital".11

The remaining staff members give their services gratis and are outstanding specialists in their respective fields.

The appointments to the hospital medical visiting staff are made by the Director of Health. The Dean of the Medical School subrits to the Director of Health a list of nominations for such apoointments after the list has been approved by the Hospital Staff Executive Committee.

The Director of Health may reject any of the names and call for other ones, but he agrees not to appoint anyone else to the visiting staff except on nomination by the Dean with the approval of the Hospital staff Executive Committee.

The Jurior and Senior Intemes and residents are appointed by the Director of Health after having been recomended by the Dean of the Hedical School.

Heads of the professional and semi-professional

12. R. A. Griswold, University of Louisville School of Medicine and Louisville City lospital, Pamphlet 
services which include:

1. Wedical and Surgical service

2. Niedical records and library

3. $x-r a y$

4. Laboratories

5. Special therapy

6. Diagnostic aids

7. Anaesthesia

8. Pharmacy

- Nursing care

10. Nursing education

11. Dietary

12. Social service

13. Out-patient department

are appointed by the Director of Health. The Staff Executive may submit to the Director of Health for such appointments, nominations which have been approved by the Hospital Staff Executive Committee.

Removals can be effected only by the Director of Health. The Superintendent or the Staff Executive, however, may prefer changes against any resident or member of the visiting staff, and these charges mut be considered by the Hospital Staff Executjve Committee, and the Conmittee must grant, the accused the right of a hearing. The Committee makes recommendations which are given over to the Director of Health for final disposition. The Staff Executive may request the removal of any of those emplopees directly concemed with the care and treatnent of patients if he feels them guilty of neglect, misconduct, or general incompetence. Likewise the Superintendent may rerequest the removal of any of the internes or other employees connected with the professional staff, provided he first 
notifies the Staff Executive of his intent to do so, and gives the University authorities reasonable opportunity to rectify any undesirable condition under their control. 
SOCIAI SERVICE

In the early days of the Social Service Department there was a feeling of inadequacy expressed by the Director of/ $/$ ielfare Leaguel2 regarding the personnel of the Social Service Department. An attempt was made during these years to secure standards of an adequate set-up from centers of activity such as the Iakeside Hospital, Cleveland, Ohio, and the National Organization of Hospital Social Service Association. The need for trained personnel was keenly expressed, but the Department of Public Safety 13 was not yet ready for such services. The years preceding 1929 were formative ones, and their contribution cannot be underestimated, but throughout this time there was a feeling of insecurity, of instability, and of uncertainty. There was very little continuity as to personnel and few of the workers were trained in the social service field. With the appointment in $1929, / \mathrm{a}^{\mathrm{f}}$ trained medical social worker from the University of Chicago the department came under a person with professional standing, and that fact in itself meant a distinct step forward in the standards of the department.

The Griffenhagen Associates in their recent report recommend that the director of the Social Service Department be appointed from nominations made by the head of the 12. Became the Community Chest in 1924

13. The Social Service Department at this time was sonsored by this department 
Department of Sociology and Social work of the iniversity of Louisville, the Dean of the Hedical School and the President of the University. The obvious intention of the recommendation is to place the position of the Director of ledical Social Service on a genuinely professional basis. It recognizes the opportunity offered by the University to develop the standards of social work persomel as well as medical personnel in the hospital.

At the present time the departnent consists of a director, seven social workers, two full time stenographers, one county worker, one full time clinic clerk and three half time clinic clerks. One of the weaknesses of the departinent still iies in its inadednately trained nersonnel. of the director and seven social workers on the staff, only the director and two workers are qualified to hold membership in the social workers' professional organization, The American Association of Social Workers (see appendix $A$ ), and only the director is a nember of the American Association of ledical Social lorkers (see appenAix $B)$. Such a condition can be explained chiefly by the fact that professional services in this fielo are not as yet sufficiently understood by the general public or the municipal adininistration. 
Because of the partial acceptance of professional social services in the hospital, funds are not made available to bring experienced workers to the Louisville City Hospital. Only when the public realszes the value of employing trained personnel and is prepared to pay salaries, accordingly, will this condition be reredied.

The salaries in this department range from $\$ 618.00$ and one meal per day for a senior sterographer to $2,430.00$ and one meal per cay for the director. 
NURSING:

The School of Nursing of the Louisville City Hospital was chartered in 1889. At the present time the school consists of one hundred students. The candidates for admission to the school of Nursing should be between 18 and 32 years of age, preferably between the ages of 21 and 25. They must be in good health and sound physical condition and must be graduates of recomized high schools and stand in the upper third of the class. Married women, widows, divorcees or applicants who have been in any other school are not considered for admission.

The three year course includes, in addition to practical work on the wards and in the clinics, courses In medicine, surgerv, obstetrics, pediatrics, contagion, osychiatry, operating room technique, and dietetics. The hospital employs 45 graduate nurses, 10 of whom supervise and instruct the student nurses. In addition to courses given by the nurses, lectures are delivered by the visiting staff phrsicians.

Prior to 1932 the students were each paid 18.00 permonth in adjition to room, board and laundry, but at that time, the cash allowance was discontinued and now the student enterine school must pay 50.00 the first vear. According to the Griffemhagen Report nursing education at the Louisville City Hospital is not of the high- 
est grade because of the inadequate number of reall 7 qualified instructors anong the nurses enployed by the hospital. The hospital, in order to provide recognized nursing training must employ a number of nurses with postgraduate education in specialized fields.

The present superintendent of nurses has been errployed by the City Hospital for the past twenty years, at one time in the capacity of operatinf room supervisor. She was educated at a time when only two years of formal nursing education was required for graduation, and has had no post-craduate work. The director of mursing in any hospital, is the head of the musing organization of the hosvitalt morking under her authority are the required assistants, the supervisors of departments or sections, head nurses, nurses on general duty, and such adjunct mursing personel as orderlies and attendants. A position such as this necessaril requires a person of wide training and experience.

$$
\text { Another recommendation made by Griffenhacen }
$$

Associates was that the school be transferred to the University of Louisville, as an affiliate of the school of Medicine. Through such an arrangenent, muses would receive their technical training mider instructors provided by the Tniversity of Louisville, and would use the hospital 14. Walcolm Haciachem, Hospltal Organization and hanagement, po. 391 
for the practical application of their mowledge. The plan would be much the same as that which now exists between the University of Louisville medical students and the hospital, the difference being that stulent nurses would receive room, boand and laundry in reburn for services rendered. Until such a plan could be completed it was reconmended that the stuaent body be reduced from one hundrec to severty-five stucents snd that the hospital budget provide for the eroloyent of aditional graduate mirses. 
RECORD ROOH

This department established in 1823 is under

the direction of a registered medical records libramian 15

who has held the position since 1928. The Lambert System

of Classification of diseases is used, but plans are being

discussed by the staff for the use of a code, known as the

Standard Classified Nomenclature of Disease. This systern

is in use in many of the hospitals, and it is probable

that the system will become standard for all record

libraries recognized by the Anerican college of Surgeons. ${ }^{16}$

15. The narie of the professional organization for medical records librarians is known as the "Registry of Records Iibrarians"

"Oualifications for Registration: The following shall be the qualifications for registration. 1. The candidate shall be of the full age of 21 vears, ethical and of good moral character. 2. The candicate shall be a maduate of a school for records librarians approved by the Association of Records Iibrarians of North America or 3. She shall have had a preliminary education equivalent at least to a full course in a recognized high school and shall have acted in the capacity of chief records librarian in a hospital approved by the American college of Surgeons for a period of not less than two out of the past five years. 4. Any records librarian who is unable to qualify under clauses 2 and 3 of this section may subnit her apolication for registration, which application shall state in detail the qualifications of the applicant as well as her experience and training during the past five vears. The Board of Registration shall make a thorough irvestigation and shall have power to register such applicant provided it is satisfied that such registration fulfills the purpose of the registry as hereir set forth". Wactachern, Hospital organization and llanagement, pp.658

16. Winimura Standards set uo by the American College of Surgeons include: "That accurate and complete records be written for all patients and filed in an accessible manner in the hospital, a complete case record being one which includes identification data; (con't) 
The Unit System of recording such as is found in many of the hospitals including cook County in Chicago is not as yet in use at the Louisville City Hospital. Under the oresent system clinic charts and hospital charts are different in content and physical structure and are filed in senarate quarters. Under the Unit system, on the other hand, clinic and ward records are filed together. It is probable that ultimately such a systern will be established at the Louisvilie City Hospital.

In addition to the head of the department there are two full time assistants and one part time worker. The annual salaries in this department range from 756.00 and three meals per day for a full time record roon stenographer to $1,080,00$ and one meal per day for the head worler.

16. (con't) complaint, personal and family history; history of present iliness; physical examination; special examinations, such as consultations, clinical laboratory, $\mathrm{x}-\mathrm{ray}$ and other exams; provisional or working diagnosis; medical or surgical treatment; gross and microscopical pathological findings; progress notes; final diagnosis; condition on discharge; follow-up and, in case of death, autopsy findings". liactachern, Hospitel organization and wanagement Introduction 
CHAPTER VI.

PROVISIONS FOR THE WELFARE OF THE PATIENTS 
ins. come to chinic with her two smal chiloren who were founo to be nalrourishod. After studying the social situation it was found thrt fr. earning 35.00 a wonth as a jantor and that his attitudes and behavior wore very peculfir. Arrargenents were made so thet ims. " could do her husbun's work as janitor and after moh persuasion he entered the parchopatht ware for observetion. R dianosis of paresis was rade snd troetmont at the Central State Hospital, Ialelard, KY. Was recomnended. To was there for a fermonths and has returned much immoved and is now rom ing in his old iob. Durine this perios rill was sumpied for the chilorer and thet have had many izlnosses. In fact one child is still in

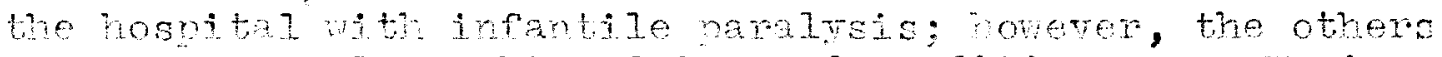
are rean nomel weight and in cood conditjon. lr. . Is still unror the care of the doctor and at tines it tales a 17. the nemsuasive pover of the social worker to keen him uncer treatment.

Tim, a ize rear old mite boy, was aduter to the hosvital threo veans aro ith a serious cardiac condition. To cane fron a fult were monk wes very imemlar and whore thare wore five chlorien of schcol ace. Tuch time was spont interpretine Tim's condition to his parents red they were found to be co-operative and understanoing. After months of hosnitelisation tim was transferrer to the convalescent tome where he rensired for many nore ronths. The social. wolker's interest cortimed ard she was as harnt as the fanily when he was allowed to retum horie. The child attends clinic, has been in school regulariy all year, and the sociel worler continues her interest in the fanily. Wen wonk is imerular the social worker supplies milk and his diet is cerefnl1 ratched. The school and church have heon norticulary helnful in understanding thjs child.

An olo colored nan was adnitted to the hosnjtal as an emergency, with a diamosis of Acute irinary Retention. This man had been wandering from place to place and it was impossible to establish legal resicence. Finally, a daughter was located in vesiem Texas end the frct that she could pive him a home was verifiec. After the patient reached his daughterls home the following letter was recejved by the social workex at the hosnital. "Pleas excuse me for not writing sooner as to let you and the ladys no that I anived home sefely and how dad they were to see ne - - they donlt even inant me to co out of the house. I arrived sooner than they were looking for me - - - on liss $X$ what nice lunch were in my 
boxes. I got to Bville sat 6:20 sharp - - my daughter belonss to the church and her prayers is Bless the sociel service for sending her daddy home to her as being only two of us after seventeen vears apart. I may of never seen my baby if not been for you - - - tell irs. $x$ I feel very well at times if feeling bad $I$ never let on. The Lord above no everything but Dr. S. and them save my life. they are kiling hogs today I were telling her how nice all of the ladies were to ne. here they never no of ny one sending people to their homes unless the money well hirs. $X$ God bless the social service and you and doctors. don't forget the ladies that is in office with you ry daughter send her best wishes and regards to you also" I close with a heart full of love to all in the hospltal in Lonisville, KY."

In. W. had a severe eoilentic seizure on the street and was brought into the nospital where he was admitted as a pationt. He and his fanily consisting of his wife and small children isved on a small truck farm at the edge of the city and lirs. Eo gave a history of repeated seizures of $r$. F. and a difficult time. Mir. F. improved, the necessary diet which he rust follow on his return hone was explaired carefully to irs. W. and she understood that he could not do many things which he had been accustoried to joire. He is under observation continuousiy and it has been bossible to secure hothers' Aid for the familv.

Alice, an old nerress, presented herself at Wedical Clinic where a diannosis of Diabetes nas made. Alice came from a mural section and was the only nember of her family to come to Louisvilie; she had been here many years working as a cook. Then she first became ill, she left hor job, thinkirs that rest would solve her problem. Her earnings were gone when she came to the clinic. It was found that she could return to her relatives and have a confortable home. The doctor felt that she should be under the care of a specialis, for a few months and then the case might be transferred to a country doctor. A home wes found in Louisvilie by the social worker where Alice's only duties were to care for the chilcren and be in the house with them when the parents were away. The social worker furnished transportation for her back and forth to cliric and when she was able to go to the country 
made the necessary arrangements for her to return to her relatives and have the required medical care.

Mir. K., an able bodied man, age 52 , with no dependents, was the victim of a severe accident while at work. He was rushed to the City Hospital as an emergency case. Wonths of hospitalization followed and he was finali, sent to the Convalescent Home where he remained a year. Both arms were paralyzed as a result of his injury. His only relative was a brother who lived alone and had a very meager income. Finally through the Conpensation Board a settlement of $51,500.00$ was made and this made it possible for Hr. $K$. to live with his brother and employ someone to stey with him during his brother's work hqurs. With the estabishment of the Physiotherapy Clinic, he has been receiving treatments twice weekly and has improved to such an extent that he is now able to dress and shave himself. The prognosis is fair, but he undoubtedly can never return to his old occupation of a carpenter, and the case cslls for continued observation and social as well as medical treatment.

R., a little girl 13 years of age, cane to lye CIinic having been sent by the school. A diagnosis of Trachoma was made. Immediate care was necessary and school attendance was prohibited. The family were poor and ignorant and it took a great deal of effort to persuade the parents to bring all of their children to clinic for examination. A diagnosis of Trachora was made on three of the children and the mother. Frequent clinje visits were made and each time it was necessary for the worker to explain the great necessity for continued care. The mother and two of the children have been discharged as cured.

Mr. H., a white man aged 32 years, during an 11lness learned to know the social worker and later when his wife was not well he appealed to her for help. The wife was brought into clinic and a diagnosis of early Carcinoma was made and sursery advised. This noesented a real problem because Irr. I., who at one time had earned

1. This clinic was established during the latter part of the year 1935. The department was set up after the Poliomyelitis epidemic in Louisville during August and September, 1935. Through the efforts of a department of the Louisville Courier-Tournal, Fresh Hope Fund, funds were raised, and it is from these funds that the work of this department is carried out. 
ip 50.00 a week, at this time had only a fev days work a week and a weekly incone of about 14.00 . There were five children, azes 2 to 10 vears. After a conference between $\mathrm{hr}$. and $\operatorname{Mrs}$. H., the doctor and the social worker, an operation was advised. The worker wrote to Iirs. H's mother who lived in the country and arrangements were made for her to stay with the children during Mrs. H's hospitalization. This operation was performed two vears ago and irs. H. is now in good condition. Subsequent examinations show no recurrence of the disease. Hir. IT is still working on part time, but recently he has had more days of work. The social worker is still in tovch with the family; the worlan needs to be under observation and several times when the children have been ill, help has been necessary.

li., an attractive young white Ejrl, 20 years of age, presented herself in Prenatal clinic. She was unmarried and living with her widowed mother whose only source of income was the eamings of a 22 year old son. M. requested hospltal care and also requested that the social worker place her baby for adoption. The worker visited the home and found the mother distracted and eager to shield her daughter and thought adoption of the baby the only possible olan. The baby was born in the City Hospital. After interpretation of the problem by the social worker, the mother's attitude changed and li. went horle with her baby and was welcomed by her mother and brother. The worker kept in close touch with the family, became acquainted with the father of the child and found he was apparently very sincere in his affection for $\mathrm{H}$. The baby is now a vear old; its nother and father were married six months ago and are now in their own hone, which is apparently established on a satisfactory basis.

A 13 year old white child was hospitalized twice during the past year for Pyelitis. After returning home she showed anxiety and self-pity and was inclined to think of herself as an imvalid. Her school atteniance was irregular and she complained continuously of a pain in her side. The father was unemoloved and the mother was doing day work, supporting the fanily. one other child with a defomed foot and the riatemal erandmother made up the household. After re-exarnination the patient was 
found to be in good ohysical condition. The doctor, social worker and mother conferred and the case was interpreted as a social rather than a medical problem. Recreational opportunities were developed, the father was assisted in securing employment, the case was interpreted to the visiting teacher, the child was helped in making up the work which she had missed in school. The broken church connection was re-established and arrangements have been made for the maternal grandrother to spend some of her time with her other children. The brother has been seen by an Orthopedic Surgeon and special shoes have been provided for him.

The preceding brief statements are given to show some of the typical medical-social problens which are presented by patients when they apply at the Louisville City Hospital for medical care.

our theories in regard to disease in the past century have been ereatly modified by the contributions of bacteriology, of saritary engineering and of mental hygiene. With increased knowledge we have made progress in explaining disease and in providing treatrent. We no longer think of disease as an entity, it is rather that of an individual reaction to certain disturbing stimuli, with indications as to treatment and outcome.2 viewing aisease in the light of this concept it became clear to the physician, by the end of the last century, that man as a physical being could not be separated Iroin man in his social settirg; man in his entirety or as near entirety as

2. Wm. A. White, H.D. The Weaning of Disease 
possible must be studied and treated. Bacteria, bad housing, lack of rest, malnutrition, inadequate wages, etc., axe all factors which act as stimli and contribute to the disturbance which we have cone to call disease. In order to make treatrent effective we are beginning to see that it is necessary to enlist the services of a professional person skilled in the study and interpretation of the whole patient, including his hereattary, enviromental, developmental, physical, peycholoeical, omotional, econonic and educationel history. This contribution in the understanciins of disease was made in the first instance by the ceneral practitioner and is increasingly understood because of the services of the modern medical-social worker. 3 She has leamed man as an incividual, as a member of a fanily group, a community proup, as a participant in an industrial system which frequently does not supply hin with wages adequate to provide for his fantit auring periods of IlIness; she has leamed to umerstand tho atitudes and emotions of the patient and those of his family and friends toward 1 Iness and sees wherein they are valuable or detri-

3. It was Di. Fichari Cebot who introduced the social worker as a definite factor in medical treatuent. Who first medical social semice departent was established at the inassachusetts General Tospitel, Boston, in 1905. By 1932 there were 529 social service departments in 6,093 hospitals in the United States with an estimated total of 2,000 medical social worleers. of the 100 hospitals in Kentucky, two institutions, exclusive of the Louisville City Hospital, The Children's Free Fospital, Iouisville, and the John horton Memorial Infimary, Louigville, have berinnings of departitents in the work which is being done by a social worker at each of the hospitals. 
mental in helping the petient in his mecical-social adjus tment.

"orking together, the physicin and sociel womer must take comizance of the assets and linitations of the petiont and nave neoical-cocial plans, which, with the patient's comoration, will hezo him re-ajiust to society on a nhrsical end social level which he will be able to achiove.

The social service doperthent at the Iouisville City Hospital is still in the axocess of developing. The depantrent recomizes its Iinitations wich are due in oant to various circuistances. (1) in inadequate staff, not all newore of wich are professionaly brained.(2) The Great intake on the wards and in the olinjos and the rapid

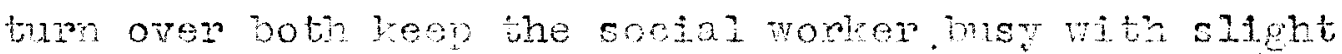
servioe cases, and doos not allow enongh time for continued social case work. (3) ligny tasks, such as placing anbuance pus, roferral of physician's orders to the Fublic Jealth Wursint ssociation, are done oy the social worker. Clerical holp shond be provided for these routine services, in oper that me nocial worken hat have none time to spend doing constretive worl. (4) rany medical-social plans wich are nade connot be camied out because of the lack of commuity resoupces. Such is trie 
in cases of chroric incirables, and in those cases which are in need of vocational rehabilttation.

In spite of the linitatione nemtioned, the services which are renoered by the department are recognized as an integrol part of medical treatwent, tiey are widenIng in scope and comine attempts are being made to raise stancards of personnel, of case work for ratients, and of organization and acministration of the denartrent. 


\section{CONCLUSION AND RECOMMENDATIONS}


The preceding study has attempted to show the Louisville City Hospital as a vital municipal institution which is evolving to meet the needs of the indigent sick of Louisvilie. This evolution has been possible, in part, because of the developing social consciousress of the citizens of Iouisville.

only when we view the institution in perspective and In its totality can we understand and interpret its policies and practices. The present character of the hospital has been influenced by nunerous factors; the changing city adrinistrations, the awakening of the citizens of Louisville to problems of social well-being, the relation of the Hospital to the University of Louisville liedical School, the recent social approach to the treatment of disease, these and various other factors have played a part in determining the current provisions for the sick poor of the cit.

Louisville has had made, in the past twelve years, four important studies in respect to its health. agencies and practices, and sections of these have been quoted in the body of this dissertation. The conclustons reached and recommendations made were the result of serious investigation by men with professional skills, authorities in the fields of public health and hospital 
organization, management and efficiency.

With these men, our own brief study concludes that it is possible for this city to provide adequately and efficiently for all the needs of its sick poor, but in order to do so further evolution must take place, and higher social standards be achieved.

Judging from recent trends, we believe ourselves justified in stating that before too long the health services of the city will be removed from political control, that personnel appointments will be made on the basis of ability and professional training, that improved accomodations for the isolation of commulcable diseases and more adequate professional nursing services will be provided, that the social service departwent will be staffed more adequately and with fully qualified workers, and possibly that the health department and the hospital will be changed from a city set-up to a city-county unit supported from combined city and county taxes and admiristered for the entire sici poor population of Jefferson County.

Through the years, since the establishinent of the Louisville Hosnital Company in 1817, we see that there have never been radical changes in the history of the hospital. Progress which has been made has been slow, but has brought with it an increasing uncerstanding of 
the needs of those not secure enough economically to provide for their own medical care. A slow tedious educative process is necessary before theories, new ideas and practices, such as non-political control of the hospital, trained persomel, etc., are accepted by the community in general, but once this group does incorporate these new standards into their plan of commuity organization, the new practices are destined to be accepted by the pubIic, becauses their values have not been forced, but have been understood and evaluated accordingly.

We conclude, therefore, that new administrative practices will be introduced sradually, more adeguate funds allocated for trained peisonnel, and further advancement/in hospital organization and manasenent, as the evolution of the Louisville city Hospital keeps step with the progress of a denocratic commuty. 
BIBIIOGPAPHY 


\section{BIBLIOGRAFITY}

Collins, Gabriel, Iouisville Directory 1836, 1838-39, $1843,1844,1848$

otis, Richard, Iouisville Directory 1832

Jegli, J.E., Iouisvilte Directory 1845-6, 1848, 1849 , $1851-52$

Campbells, J.D., Louisvilie Directory 1861

Hohurtrie, fenry, Sketches of Louisvizle

Johnston, J.I., Memomal History of Louisville

Smith; Z.F., History of Kentraky

Casseday, Benjamin, History of Ionisvinie

otis, R."., outline of the origin and settlement of Louisville

Collins, R.H., History of Louisville

Rafinesque, Schmeltz, History of Kentucky

Robertson, James R., Fetitions of the Farly Inhabitants of. Kentucky

Caron, C.K., Comp, Gemen \& Bros' Lonisville ditr Guide and Business Directory $1869-70$

Loufsville Directory and Anmal Business Acvertiser, 1850-58 Brown, John Rason, Political Beginnings of Kentucky

Kentuclry Laws, Statutes. Acts of the Generel Asserniy of Kentucly, $1809-1937$

Wisconsin state Historical sondety, Celencier of the Kentucky Papers

Loulsville Kentucky General Council Annual Reports 1866 , $1868,1870,187 \%, 1912$

Charter of the city of Iouisville, 185]-1854, 1857, 1862

Griffenhagen Associates, Renort, on the innicinal fovernment of the City of Lonisvilite 1934-35

Kopeloff, Nicholas, Wan Vs. Microbes 
Bossard, James F.S., Problens of Social Mell Feind Gillin, T.I., Poverty and Dependency

Davis, H.M., Clinfes, Hospitals and Health Centers Sigerist, Fenry, American liedicine

Final Report of the Committee on the costs of Hedical Care, Nedical Care for the Arerican People

Strone, H. Public Velfare Adniristration in Canada

Emerson, Iaven, and Philips, A.C., Iosultals and Iealth Agencies of Louisville: A Survev, 1924

White, I..D., Trends in Fublic Administration

Rich, Enid, History of Cook County Hospitel, Naster's Thesis, University of Chicago, 1927

Kentucky hedical Joumal February 1935

NacIver, Robert, Society: Its Structure and Changes

White Iiouse Conference, Report on Hedical Care, Social Service and Fospitals

Griswold, R. A., Tniversity of Louisville School of leodicine and the Louisvilie City lospital, Pamphlet

Horine, F.F., History of the Lonisvinle redical Institute. and of the Establishment of the University of Louisvilie and Its school of inedicine. Filson Club Fulication

Baker, E.N., Tditor, 1s83, A Complete Foclet Guide to Interesting and Important, flaces in the City of Iouisville Kentucky

Moore, Herry H., Public Fealth in the United States

Kelso, Robert, The Science of Public Welfare

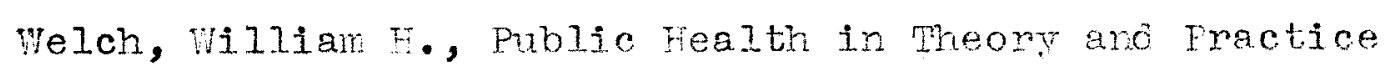
Bouvier's Law Dictionary

Davis, M.M., liedical Soc1al Work Irplications of Studies Niade by the Committee on the Costs of ivedical Care

Corpus Juris, Section on Paupers

Ruling Case Law, Section on Poor and Poor Laws 
American Academy of Folitical and Social Science, The Public Health vovenent

Perrin, Battle and Kniffin, Kentucky: A History of the State, 8th Edition

Joblin, i. \& Co., Louisville Past and Present

ivathews, J.I., Wemorial History of Iouisville, Volume 2

Abbott, Eaith, Abolish the Pauper laws, Social Service Review, Volume 7, No.1

Hicks, Nary I., Socikl. Service in the Hospital Program

Parr, Pauline, The hedical Soctel Worker ir a Public Iristitution

Social Work Year Book, 1933, Section on viedicine and Social Work, section on Yospital social rork

Encyclopedia of the Social Sciences, Volume 10, Section on Medicine

State Board of Health of Kentucky, Edo, hedical and Health Laws of Kentuch

Fublic Health Services, Cleveland, Ohio, Fosnital and Heal th Surver

Durrett, R.T., Centenary of Louisville, 1880, Filson Club Publication No.8

Study of one Heek's Hospital and Clinic Admissions at the Louisville Gity Hospital. Harch 13, to 20,1934

Baldwin's Revision, Supplement to 1933, Carroll's Kentuck Y Statutes

Cannon, Ida, Social Work in Hospitals

University of Lonisville Bulletin, School of Nedicire 1935-36

Buck, Carl F., Survet and Appraisal of Health Activities and Needs of Louisvilie Kentucky, 1935

MacEachern, Malcolm, Hospital Organization and lanagement Cabot, R.C., Medical Social Work, A Characteristically American Product 
Annual Revorts Louisville Hospital Company, 1817-1840 Annual Reports Louisville Marine Hospital, 1857, 1866, $1868-70$

Annual Reports Loulsville City Fiospital, 1872-1907, $1910-1915,1915-1936$

Correspondence on the Social Service Department at the Louisville City Tospital, on File with the Health Council, Loulsvilie Community Chest 
APPTDIXIS 


\section{APFEIDIX A.}

THE REQUIRE IETSS FOR WEIBERSHIF IN THT AITRICAN ASSOCIATION OF SOCIAI WO TIERS

ualfications for Junior Wonerehip

(1) Winimm age of 21 years.

(2) Completion of at least bro years morr in an anoroved coliege.

(3) Three additional years of ceneral education, technical training or empoment in an approved ocenor. The nequinenent may be satisfied In either one of the tho following wars:

a. Completion of two additional pens work in an aporoved college plus ore vearts work in an approved school of social work. - Three vears spent in some combination of: attendance at an approved collece, attendance at an aproved school of social work, or enplovent in an aporoved agency, provided, however, that the applicant has satisfactorily completed:

25 serester hours of social and biological science in an approved college or sohool of social wonk:

10 sementer hours of approveu techical social mork courses.

300 hours of supervised field work in connection with technical social work courses. 
(4) Minlowent at the time of application in sn approved agency. Walifications for lembership Arplicants for herbership shall after July 1 , 1053, have the following qualifications for admission to membership in the Association:

(1) Completion of at least two rears' work in an apropoded collere.

(2) Wive adutional years of general education, technical training or employruent in an approved agency. This requirenent mat be saticfied in either one of the two following ways:

a. Cratiation from an approved college plus. one year in an approved school of social work, plus two rears of ewploment in an approved acency.

- Five vears spent in some combination of: attendance at an approved college, attendance at an aporoved school of social work, or omployent in an approved agency, provided, however, that the avolicant has satisfactorily comleted:

20 senester hours of social and biological 
science in an approved collegre or school of social work

24 semester hours of anproved technical social work courses.

300 hours of supervised field work in connection with the technical social work courses.

Two vears of emploment in an approved agency.

(3) (Substitute for requirements 1 and 2 )

Greduation from a four year college plus completion of a two year graduate course in an approved school of social work shall be regarded as fulfilling requirerients 1 and 2 .

Section 5. To ore nay continue as a Junion Wember after he becomes eligible to full nembership. No one mat remain a Tunior liemer more than five rears unless granted extension for cause by the Executive Comitiee.

Section 6. The Ixecutive Connittee may in exceptional circunstances elect to menbersip persons who do not techically meet the requirements specified above. 
TIE QUALIFICATIONS OF TRAINING AS REQUIRED FOR ELIGIBILITY TO IVENBERSHIP IN TIE AWILICAN ASSOCIATICN OF MEDICAL SOCIAI WORFERS

Craduated from a school of social work aporoved by the mecutive Comittee as hereinafter specified.

Completed a full course in medical or psychiatric social work and having one rear's experience in the practice of the same, or as an altemative, paken a full course in any other tyoe of social work and having 18 months' experience in the practice of nocical on psychiatric social work. obtained a bachelor's derree or its equivalent (to be determined by the mxecutive Comittee), at least two rears of supervised case work experience in a recognized rocisl arency (this beine understood to include a medical social agenct neetim the rermirements of minimu standards of the Anerican lssociation of liodical social orkers), and has had in addition 18 months' oxperience in the practice of medical or verchetric social work

Completos at least two rears of suporvised case work emperiance in a recomized social auenoy (this being muerstood to incluce a wedical social agenct neeting the requirenent of riniman standards of the American Association of Medical Social Torkers), and has had in addition 
3 years' experience in the practice of medical or psychiatric social work.

Consiciered by the Executive Comittee to be a verson of exceptional ability who lacks sufficient formal edueational experience, but who has had five jears or more of experience in social work of which not less than three years have becn spent in the practice of medical or psychiatric social work.

Gradusted from an accredited high school or its equivalent and has graduated from an accrodited school of nursing, and has had at least 2 years of supervised case wor experience in a recognized social agency and has had, in adoition, 18 months experience in the practice of medical or psrchiatric social wor. 